\title{
A Review on Infrared Spectroscopy of Borate Glasses with Effects of Different Additives
}

\author{
Chandkiram Gautam, Avadhesh Kumar Yadav, and Arbind Kumar Singh \\ Department of Physics, University of Lucknow, Lucknow 226007, India \\ Correspondence should be addressed to Chandkiram Gautam, gautam_ceramic@yahoo.com
}

Received 12 July 2012; Accepted 26 August 2012

Academic Editors: Y. S. Cho, D. Jia, M. Kawashita, and C.-F. Yang

Copyright () 2012 Chandkiram Gautam et al. This is an open access article distributed under the Creative Commons Attribution License, which permits unrestricted use, distribution, and reproduction in any medium, provided the original work is properly cited.

\begin{abstract}
Borate glasses are the technologically important class of glasses and play a significant role in various applications. Borate glasses contain planar $\mathrm{BO}_{3}$ groups as structural units, rather than tetrahedral $\mathrm{SiO}_{4}$ groups. The oxygen atoms are, as in $\mathrm{SiO}{ }_{2}$, again connected to two network-forming atoms, in case of boron. The radial distribution analysis describes the $\mathrm{B}_{2} \mathrm{O}_{3}$ glass structure as consisting of boroxol rings, that is, planar rings containing three boron atoms and three oxygen atoms. The network forming of the $\mathrm{B}_{2} \mathrm{O}_{3}$ and the $\mathrm{SiO}_{4}$ is affected with the addition of some metal cation additives $\mathrm{Pb}, \mathrm{Zn}, \mathrm{Cd}$, and so forth. These additives also work as a network modifier and a nucleating agent for crystallization of glass. Therefore, the optical properties of the borate glasses have been changed significantly.
\end{abstract}

\section{Introduction}

Glasses are supercooled liquids, transparent, and amorphous in nature. They are inorganic product of fusion which has cooled to a rigid condition without any crystallization. The main distinction between glass and crystals is the presence of long-range order in the crystal structure [1]. The optimization of such properties as a function of composition and other processing parameters requires a good knowledge of the microscopic glassy structure. For many years, glasses containing transition metal ions have attracted attention because of their potential applications in electrochemical, electronic, and electro-optic devices. A host of borate rich glasses containing alkaline earth oxides along with $\mathrm{ZnO}, \mathrm{PbO}, \mathrm{TeO}_{2} \mathrm{Bi}_{2} \mathrm{O}_{3}, \mathrm{MgO}, \mathrm{CaO}, \mathrm{SrO}$, and $\mathrm{BaO}$ as glass modifiers are optimistic materials for their probable applications in the fields of optical communications (optical fibers), laser hosts, optical filters, $\mathrm{X}$ - and $\gamma$-ray absorbers, photonic devices, and so forth [2-8]. Infrared spectroscopy (IR) is an important tool for understanding the structure and dynamics of amorphous materials. It is also used to assign the observed absorption peaks to the proper vibration of the atoms in geometric grouping. The spectra of many solids variables can affect the absorption peaks, and the assignment of vibration peaks of the atoms is very difficult. Usually, the method of repeated occurrence is followed in analysing the IR spectrum of solid materials $[9,10]$. In this spectroscopy, the nature of the light matter interaction is not same as in Raman spectroscopy, and the fundamental differences of the two processes determine the selection rules, which control Raman or IR activity of normal mode of vibrations. Interaction of IR radiation with a normal mode of vibration only occurs when the electric field of radiation oscillates with same frequency as instant dipoles caused by atomic vibrations. A normal vibration is therefore, IR active only if a change in the dipole moment of the vibration occurs and is a one photon process, as only photon is absorbed [11]. Therefore, IR spectra give additional information rather than Raman spectra by which the symmetries of normal modes of vibration of molecules and crystal lattices are determined [12-15]. The spectrum of a sample is compared with the spectrum of a large number of compounds containing a common atom group or groups. Certain absorption peaks are common to certain groups and are assigned the vibration characteristics of these atom groups. Borate glasses have been the subject of numerous infrared studies because of their 
structural peculiarities [16-23]. A widespread set of very different borate glasses with optical, magnetic, superionic conductivity, and other technologically interesting properties are currently produced $[24,25]$.

\section{Infrared Spectroscopy}

2.1. Lead Borate Glasses. During the past five decades, many efforts have been taken to realize the roles of $\mathrm{PbO}$ in glass networks using different techniques [26-30]. PbO$\mathrm{B}_{2} \mathrm{O}_{3}$ glasses are of technological interests owing to their unique properties such as their low melting temperatures, wide glass formation regions, and good radiation shielding properties, [31-34]. IR spectra of the various $\mathrm{PbO}-\mathrm{B}_{2} \mathrm{O}_{3}$ glasses are shown in Figure 1. The nomenclature of these glasses has been listed in Table 1 . IR spectra of pure $\mathrm{B}_{2} \mathrm{O}_{3}$ gives two absorption band at wavenumbers 1300-1700 and $720 \mathrm{~cm}^{-1}$. The absorption bands at wavenumbers range of $1300-1700 \mathrm{~cm}^{-1}$ are attributed to the bending vibration and stretching vibration of $\mathrm{B}-\mathrm{O}-\mathrm{B}$ in $\left[\mathrm{BO}_{3}\right]$ triangles $[35$, 36]. The addition of $10-20 \mathrm{~mol} \% \mathrm{PbO}$ does not affect borate network. The absorption bands below $620 \mathrm{~cm}^{-1}$ are attributed to vibration of $\mathrm{PbO}$ [37]. Therefore, $\mathrm{PbO}$ acts as a network participant filled in the interspaces of $\left[\mathrm{BO}_{3}\right]$ units in the form of $\mathrm{Pb}^{2+}$ ions (Figure 2(a)). The electrostatic fields of the strongly polarizing $\mathrm{Pb}^{2+}$ ions are affected with increase of $\mathrm{PbO}$ content, which might serve to increase the wavenumber of $\mathrm{B}-\mathrm{O}-\mathrm{B}$ bending vibrations [38]. Absorption band between 900 and $950 \mathrm{~cm}^{-1}$ was observed due to the stretching vibration of $\left[\mathrm{BO}_{4}\right]$ units [39]. This indicates that the addition of $\mathrm{PbO}$ leads to the conversion of $\left[\mathrm{BO}_{3}\right]$ units to $\left[\mathrm{BO}_{4}\right]$ units in borate glass, which is also confirmed in glass system of $\mathrm{CeO}_{2}-\mathrm{B}_{2} \mathrm{O}_{3}$ and $\mathrm{La}_{2} \mathrm{O}_{3}$ $\mathrm{B}_{2} \mathrm{O}_{3}$ [39-41]. Moreover, with increase of the content of $\mathrm{PbO}$ from 30 to $50 \mathrm{~mol} \%$, the frequency of $\left[\mathrm{BO}_{4}\right]$ unit shifts from $945 \mathrm{~cm}^{-1}$ to a lower wavenumber $931 \mathrm{~cm}^{-1}$. This may be due to the formation of bridging bonds of $\mathrm{Pb}-\mathrm{O}-$ $\mathrm{B}$ (Figure 2(b)). Since the stretching force constant of $\mathrm{Pb}-$ $\mathrm{O}$ bonding is substantially lower than that of the $\mathrm{B}-\mathrm{O}$, the stretching frequency of $\mathrm{Pb}-\mathrm{O}-\mathrm{B}$ might tend to be lower. Another dominant shift in the glass (30 $\mathrm{PbO} 50 \mathrm{~mol} \%)$ is the sharp decreasing trend from 1360 to $1315 \mathrm{~cm}^{-1}$. Lorösch et al. [42] attribute the broad bond of about $1300 \mathrm{~cm}^{-1}$ to the vibration of $\mathrm{B}-\mathrm{O}$ rings composed by $\left[\mathrm{BO}_{3}\right]$ and $\left[\mathrm{BO}_{4}\right]$ units. Therefore, the presumption that $\mathrm{B}-\mathrm{O}$ rings are formed in the glasses by the connection of the bridge oxygen ions between $\left[\mathrm{BO}_{3}\right]$ triangles and $\left[\mathrm{BO}_{4}\right]$ tetrahedrons can be made (Figure 2(c)), due to the decreasing frequency of the stretching vibration of $\mathrm{B}-\mathrm{O}-\mathrm{B}$. Subsequent additions of $\mathrm{PbO}(60-80 \mathrm{~mol} \%)$ have the same effect on the structure of glasses. The biggest shift of $916-876 \mathrm{~cm}^{-1}$, observed in $\mathrm{PB}-8$ sample, indicates that when the content of $\mathrm{PbO}$ is up to $80 \mathrm{~mol} \%$, the content of $\mathrm{Pb}-\mathrm{O}-\mathrm{B}$ becomes dominant in the glass network structure. It can be presumed that the increasing polarization of $\mathrm{Pb}^{2+}$ with the increase content of $\mathrm{PbO}$ contributes to the formation of $\mathrm{Pb}^{2+}$-modified boronoxygen rings and their chains. New bands at 1016 and $1020 \mathrm{~cm}^{-1}$ of PB-6 and PB-7 glasses can be attributed to

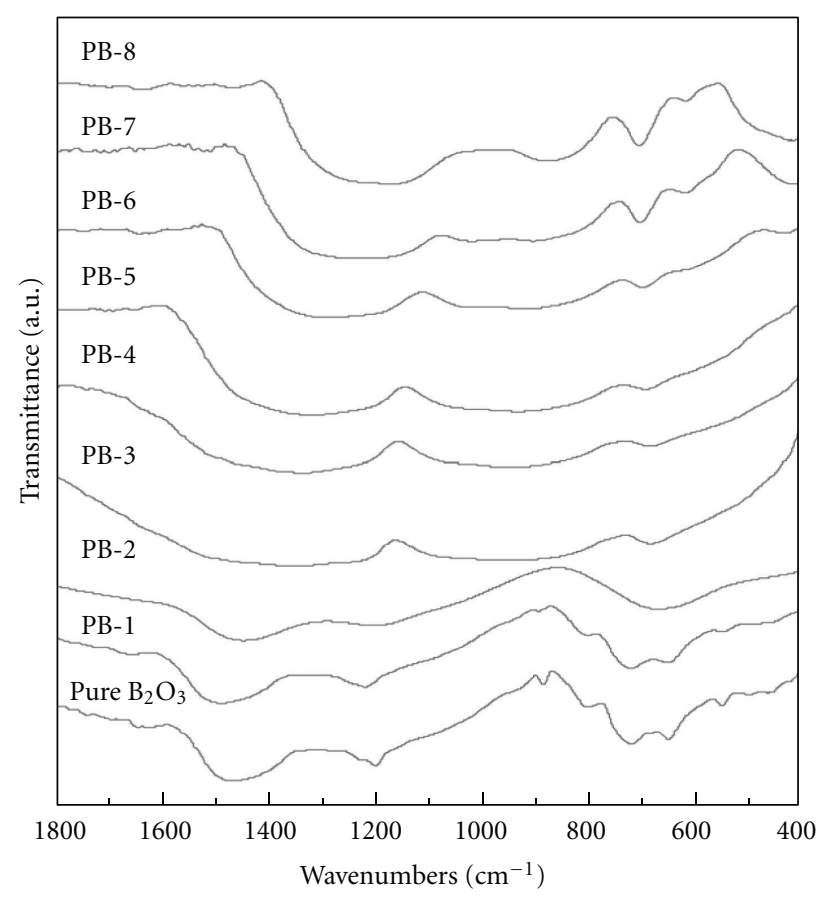

Figure 1: Infrared absorption spectra of $\mathrm{PbO}-\mathrm{B}_{2} \mathrm{O}_{3}$ glasses [34].

the absorption vibration of $\left[\mathrm{BO}_{4}\right]$ units [43], indicating the increasing content of $\left[\mathrm{BO}_{4}\right]$ units in glassy networks. The absorptions of $\mathrm{PbO}$ (below $620 \mathrm{~cm}^{-1}$ ) show that $\mathrm{PbO}$ is one of the good network former of glasses in this region. Apart from the above discussions, it can be concluded that as $\mathrm{PbO}$ content exceeds $60 \mathrm{~mol} \%$; five bridging oxygens may be involved in glass networks: $\mathrm{B}-\mathrm{O}-\mathrm{B}$ in $\left[\mathrm{BO}_{3}\right]$ and $\left[\mathrm{BO}_{4}\right]$ units, the bridging oxygen ions between $\left[\mathrm{BO}_{3}\right]$ and $\left[\mathrm{BO}_{4}\right]$ units, $\mathrm{Pb}-\mathrm{O}-\mathrm{B}$ in bridge connection of $\left[\mathrm{BO}_{3}\right]$ and $\left[\mathrm{BO}_{4}\right]$ units, and $\mathrm{Pb}-\mathrm{O}$ in covalent bonds (Figure $2(\mathrm{~d})$ ). Molecular dynamics represented that the radial distribution pattern is consistent with structures having a low concentration of such rings [40]. Although borate glass forms a three-dimensional network, its viscosity is substantially lower than that of silicate glass. Again, addition of alkali lowers the viscosity of the melt, but the effect is by no means as dramatic as for silicate glass $[44,45]$. Introduction of alkali or moisture to alkali metal borate glasses causes some of the three-coordinate boron atoms to become four coordinate $[46,47]$. The addition of various constituents in $\mathrm{PbO}-\mathrm{B}_{2} \mathrm{O}_{3}$ also affects the structural properties of these glasses.

2.2. Barium Lead Borate Glasses. IR studies of BaO-PbO$\mathrm{B}_{2} \mathrm{O}_{3}$ glasses were reported by Schwarz and Ticha. In this study, it is seen that structural groups $\mathrm{BO}_{3}$ and $\mathrm{BO}_{4}$ can form borate networks [48]. These structural groups makes the complexity due to extensively overlapping bands, and they cover the spectral range from $600 \mathrm{~cm}^{-1}$ to $1500 \mathrm{~cm}^{-1}$ [56]. Figure 3 (1, 2-9) show the IR spectra of various $\mathrm{BaO}-\mathrm{PbO}$ $\mathrm{B}_{2} \mathrm{O}_{3}$ glass samples. The compositional distribution of these glasses has been listed in Table 2. B-O stretching of trigonal $\mathrm{BO}_{3}$ units of vibrations $1200-1500 \mathrm{~cm}^{-1}$ and $850-1200 \mathrm{~cm}^{-1}$ 
TABLE 1: The molar compositions of $\mathrm{PbO}-\mathrm{B}_{2} \mathrm{O}_{3}$ of various glass samples [34].

\begin{tabular}{lcccccccc}
\hline No. & PB-1 & PB-2 & PB-3 & PB-4 & PB-5 & PB-6 & PB-7 & PB-8 \\
\hline \multirow{2}{*}{ Compositions } & $0.1 \mathrm{PbO}$ & $0.2 \mathrm{PbO}$ & $0.3 \mathrm{PbO}$ & $0.4 \mathrm{PbO}$ & $0.5 \mathrm{PbO}$ & $0.6 \mathrm{PbO}$ & $0.7 \mathrm{PbO}$ & $0.8 \mathrm{PbO}$ \\
& $0.9 \mathrm{~B}_{2} \mathrm{O}_{3}$ & $0.8 \mathrm{~B}_{2} \mathrm{O}_{3}$ & $0.7 \mathrm{~B}_{2} \mathrm{O}_{3}$ & $0.6 \mathrm{~B}_{2} \mathrm{O}_{3}$ & $0.5 \mathrm{~B}_{2} \mathrm{O}_{3}$ & $0.4 \mathrm{~B}_{2} \mathrm{O}_{3}$ & $0.3 \mathrm{~B}_{2} \mathrm{O}_{3}$ & $0.2 \mathrm{~B}_{2} \mathrm{O}_{3}$ \\
\hline
\end{tabular}

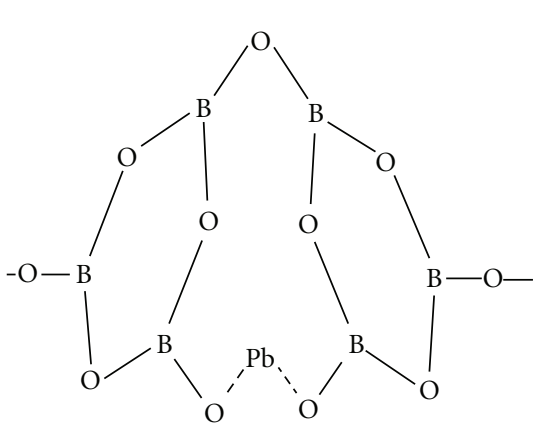

(a)

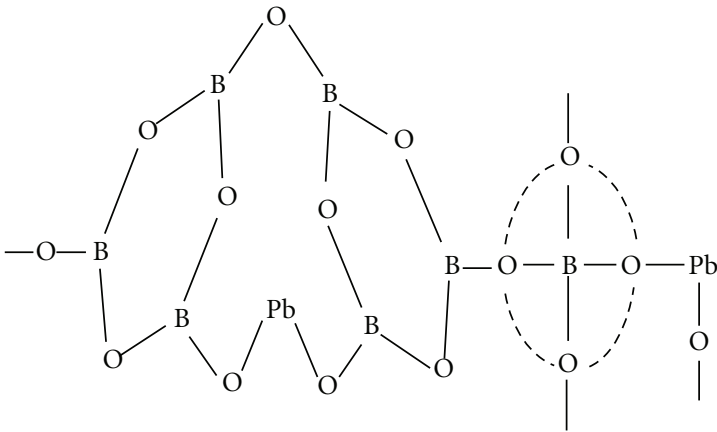

(b)

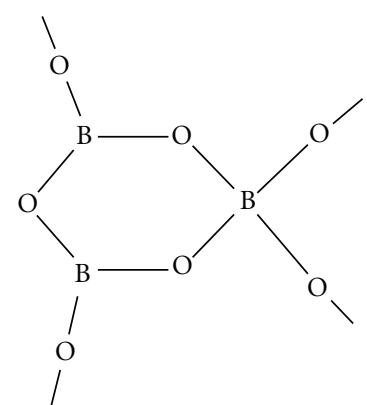

(c)

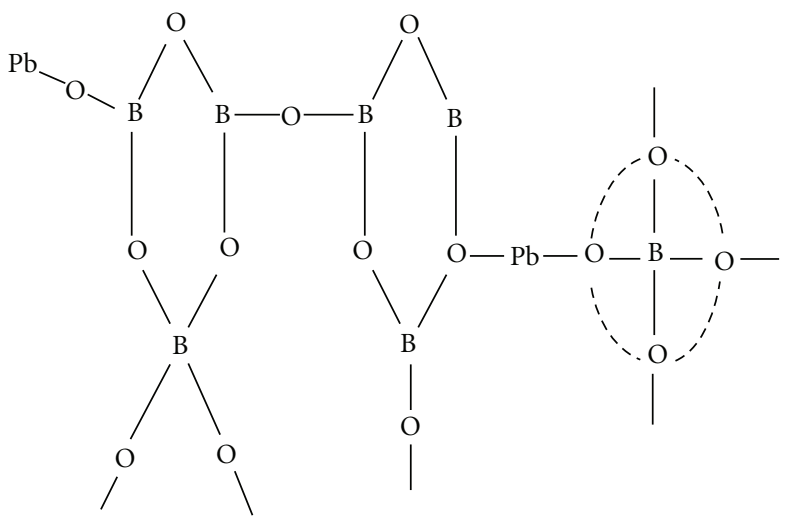

(d)

Figure 2: Possible structural units of $\mathrm{PbO}-\mathrm{B}_{2} \mathrm{O}_{3}$ glasses: (a) three coordinated boroxol rings modified by $\mathrm{Pb}{ }^{2+}$; (b) formation of $\mathrm{Pb}-\mathrm{O}-\mathrm{B}$ covalent bands; (c) bridge networks between $\left[\mathrm{BO}_{3}\right]$ and $\left[\mathrm{BO}_{4}\right]$ units; (d) complex structures of $\mathrm{Pb}^{2+}$-modified boron-oxygen rings and chains [34].

is due to $\mathrm{B}-\mathrm{O}$ stretching of tetrahedral $\mathrm{BO}_{4}{ }^{-}$units, while $600-800 \mathrm{~cm}^{-1}$ is due to bonding vibrations of $\mathrm{B}-\mathrm{O}-\mathrm{B}$ groups in various borate segments [57-59]. The IR response in the other two spectral regions changes significantly with the increase of $\mathrm{PbO}$ content. The intensity of two broad IR features, $850-1200 \mathrm{~cm}^{-1}$, due to $\mathrm{BO}_{4}^{-}$units decreases with increase of $\mathrm{PbO}$ content. Thus, $\mathrm{PbO}$ enters to the network as a network former. A spectral band at $806 \mathrm{~cm}^{-1}$ occurred due to boroxol ring formation in the glassy matrix [60].

2.3. Cadmium Lead Borate Glasses. Alemi et al. give investigations of Cd-doped $\mathrm{Pb}_{2} \mathrm{O}_{3}-\mathrm{B}_{2} \mathrm{O}_{3}$ glasses by IR spectra in the range of $400-4000 \mathrm{~cm}^{-1}$ and show their structures in Figure 4 [49]. In this study, the formation of boroxol ring and tetrahedral coordination inside the glassy matrix was not observed in IR spectra of these glasses, while the conversion of threefold to fourfold coordination of boron atoms in the structure of glasses was observed. The progressive substitution of boroxol rings by triborate and tetraborate groups is observed. In pure $\mathrm{B}_{2} \mathrm{O}_{3}$ glass, the frequency $806 \mathrm{~cm}^{-1}$ is a characteristic of boroxol ring. The vanishing of $806 \mathrm{~cm}^{-1}$ means no boroxol ring in the glass structure. This type of behavior is also observed in $\mathrm{B}_{2} \mathrm{O}_{3}-\mathrm{Li}_{2} \mathrm{O}$ glasses [67-69]. The IR spectra show the number of spectral bands which occurs due to various vibrational modes (symmetric $\left(\mathrm{BO}_{3}\right)^{3-}$ triangles, $\left(\mathrm{BO}_{4}\right)^{4-}$ tetrahedral and asymmetric $\left(\mathrm{BO}_{3}\right)^{3-}$ units (nonbridging oxygen). A broad spectral band between the ranges from 3200 to $3600 \mathrm{~cm}^{-1}$ is attributed to hydroxyl or water groups $[70,71]$. The structure of boron oxide glass consists of a random network of planar $\mathrm{BO}_{3}$ triangles with a certain fraction of sixmembered (boroxol) rings (Krogh Moe's model) [72]. These spectral bands are also seen in the borate glasses studied by Ghoneim et al. [73]. The spectral band in range from 1200 to $1600 \mathrm{~cm}^{-1}$ is due to the asymmetric stretching relaxation of the $\mathrm{B}-\mathrm{O}$ band of trigonal $\mathrm{BO}_{3}$ units, while the spectral bands lies between 800 and $1200 \mathrm{~cm}^{-1}$, and around $700 \mathrm{~cm}^{-1}$ is occurred due to the $\mathrm{B}-\mathrm{O}$ bond stretching of the tetrahedral $\mathrm{BO}_{4}$ units and bending of $\mathrm{B}-\mathrm{O}-\mathrm{B}$ linkages, respectively. The 


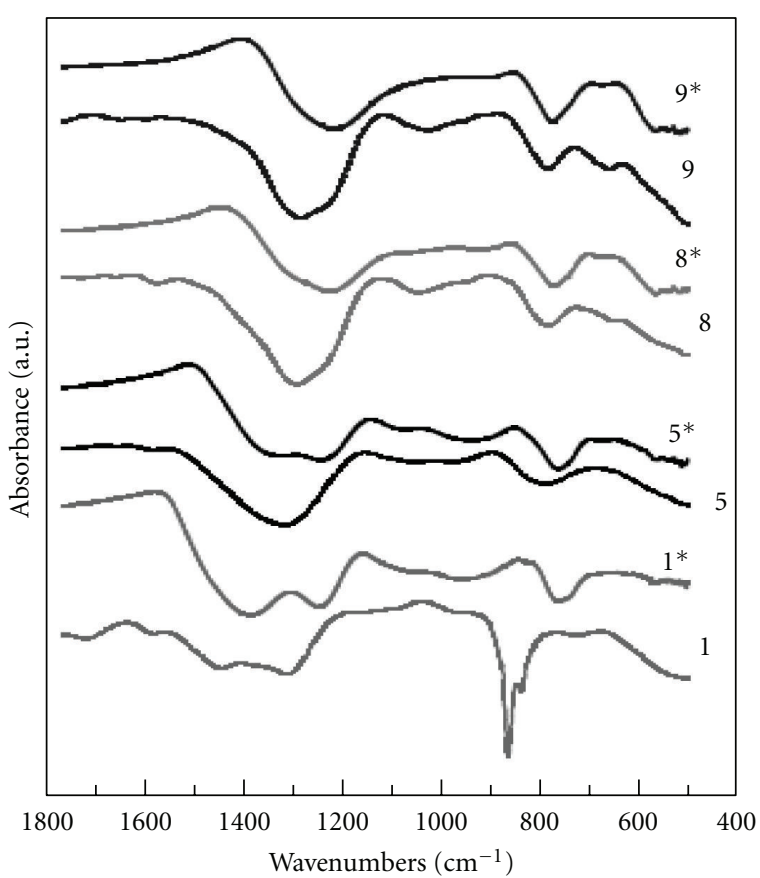

Figure 3: Raman and infrared reflectivity spectra of glass samples (*represents the Raman spectra which are not considered here) [48].

TABle 2: Compositional distribution of $\mathrm{BaO}-\mathrm{PbO}-\mathrm{B}_{2} \mathrm{O}_{3}$ glasses [48].

\begin{tabular}{lccc}
\hline No. & \multicolumn{3}{c}{$\begin{array}{c}\text { Chemical composition } \\
\end{array}$} \\
\hline 1 & $\mathrm{PbO}$ & $\mathrm{BaO}$ & $\mathrm{B}_{2} \mathrm{O}_{3}$ \\
5 & 10 & 10 & 80 \\
8 & 30 & 10 & 60 \\
9 & 50 & 10 & 40 \\
\hline
\end{tabular}

absorption peak at $1307 \mathrm{~cm}^{-1}$ is the characteristic of $\mathrm{B}(\mathrm{III})-$ $\mathrm{O}-\mathrm{B}(\mathrm{IV})$ stretching vibrations. $\mathrm{B}-\mathrm{O}$ stretching vibrations of trigonal $\left(\mathrm{BO}_{3}\right)^{3-}$ units in metaborates, pyroborates, and orthoborates are assigned at around $1357 \mathrm{~cm}^{-1}$ [74]. In these glasses, the boron is tetrahedrally surrounded by four oxygen atoms [75]. The band around $1292 \mathrm{~cm}^{-1}$ is due to $\mathrm{B}-\mathrm{O}$ asymmetric stretching of $\mathrm{BO}_{3}$ unit. The band at $1234 \mathrm{~cm}^{-1}$ was found to be $\mathrm{B}-\mathrm{O}$ stretching vibrations of $\left(\mathrm{BO}_{3}\right)^{3-}$ unit in metaborate chains and orthoborates. Nonbridging oxygen in the form of $\mathrm{BO}_{4}$ vibrations was observed at $1005 \mathrm{~cm}^{-1}$ [76]. The absorption around $1000 \mathrm{~cm}^{-1}$ indicates the formation of diborate groups in the glassy matrix. The band at about $995 \mathrm{~cm}^{-1}$ is attributed to a stretching vibration of $\mathrm{B}-\mathrm{O}-\mathrm{Si}$ linkage in the glass system $\mathrm{Na}_{2} \mathrm{O}-\mathrm{B}_{2} \mathrm{O}_{3}-\mathrm{SiO}_{2}$.

2.4. $\mathrm{MoO}_{3}$-Doped Lead Borate Glasses. The structural studies of $\mathrm{MoO}_{3}$-doped $\mathrm{Pb}_{2} \mathrm{O}_{3}-\mathrm{B}_{2} \mathrm{O}_{3}$ glasses by IR spectra show various absorption bands which are characteristics of different vibrational modes. The absorption band is at $700 \mathrm{~cm}^{-1}$ which indicates the presence of $\mathrm{BO}_{3}$ or boroxol groups in glass system containing $80 \% \mathrm{PbO}$ and $20 \% \mathrm{~B}_{2} \mathrm{O}_{3}$. The absorption bands ranges from 740 to $1120 \mathrm{~cm}^{-1}$ and from 1130 to $1520 \mathrm{~cm}^{-1}$ which are attributed to the abundance of $\mathrm{BO}_{4}$ groups and $\mathrm{BO}_{3}$ groups [76, 98-101]. The presence of water in glassy matrix was confirmed by the IR study in this system, and these bands lies in the range from 3200 to $3640 \mathrm{~cm}^{-1}$, which is related to the vibrations of hydrogen bonding, molecular water, $\mathrm{BOH}$, or hydroxyl groups [7779]. Thus, $\mathrm{PbO}$ may act as a network modifier in the same way as alkali oxide disrupting the bonds connecting neighboring $\mathrm{SiO}_{4}, \mathrm{BO}_{3}$, and $\mathrm{BO}_{4}$ groups. The ionic crosslinks provided by lead ions $\left(\mathrm{Pb}^{2+}\right)$ are stronger than those provided by alkali ions. On the other hand, $\mathrm{PbO}$ can be incorporated into the glass as network forming $\mathrm{Pb}-\mathrm{O}$ groups $\left(\mathrm{PbO}_{4}\right.$ and $\left.\mathrm{PbO}_{3}\right)[102,103] . \mathrm{Pb}_{2} \mathrm{O}_{3}-\mathrm{B}_{2} \mathrm{O}_{3}$ glasses show the formation of $\mathrm{BO}_{4}$ groups proceeds at the rate of two tetrahedral added oxygen. This formation of tetrahedral is reduced with increasing the content of $\mathrm{PbO}$ above 20\% because some of the lead atoms now participate in the network as $\mathrm{PbO}_{4}$ pyramids with the $\mathrm{Pb}$ atom forming the apex of the pyramid. These pyramids are assumed to preferentially bridge to $\mathrm{BO}_{3}$ rather than $\mathrm{BO}_{4}$ units $[6,104]$. The change in electron distribution in the $\mathrm{B}_{3}-\mathrm{O}$ bonds is at $30 \%$ of $\mathrm{PbO}$, which probably results from the replacement of $\mathrm{B}_{3}-\mathrm{O}-\mathrm{B}_{4}$ by $\mathrm{B}_{3}-\mathrm{O}-\mathrm{Pb}$ bonds. The effect of the increase in the $\mathrm{MoO}_{3}$ content is specifically reflected first in the far-infrared spectra $[105,106]$.

Various glasses were synthesized in the glass system $30 \mathrm{PbO}-4 \mathrm{MoO}_{3}-(66-x) \mathrm{B}_{2} \mathrm{O}_{3}: x \mathrm{TiO}_{2}(0.0 \leq x \geq 2.0)$ [50], and its detailed description was given as

$$
\begin{aligned}
& \mathrm{T}_{0}: 30 \mathrm{PbO}-4 \mathrm{MoO}_{3}-66.0 \mathrm{~B}_{2} \mathrm{O}_{3}, \\
& \mathrm{~T}_{2}: 30 \mathrm{PbO}-4 \mathrm{MoO}_{3}-65.8 \mathrm{~B}_{2} \mathrm{O}_{3}: 0.2 \mathrm{TiO}_{2}, \\
& \mathrm{~T}_{4}: 30 \mathrm{PbO}-4 \mathrm{MoO}_{3}-65.6 \mathrm{~B} 2 \mathrm{O} 3: 0.4 \mathrm{TiO}_{2}, \\
& \mathrm{~T}_{6}: 30 \mathrm{PbO}-4 \mathrm{MoO}_{3}-65.4 \mathrm{~B}_{2} \mathrm{O}_{3}: 0.6 \mathrm{TiO}_{2}, \\
& \mathrm{~T}_{8}: 30 \mathrm{PbO}-4 \mathrm{MoO}_{3}-65.2 \mathrm{~B}_{2} \mathrm{O}_{3}: 0.8 \mathrm{TiO}_{2}, \\
& \mathrm{~T}_{10}: 30 \mathrm{PbO}-4 \mathrm{MoO}_{3}-65.0 \mathrm{~B}_{2} \mathrm{O}_{3}: 1.0 \mathrm{TiO}_{2}, \\
& \mathrm{~T}_{15}: 30 \mathrm{PbO}-4 \mathrm{MoO}_{3}-64.5 \mathrm{~B}_{2} \mathrm{O}_{3}: 1.5 \mathrm{TiO}_{2}, \\
& \mathrm{~T}_{20}: 30 \mathrm{PbO}-4 \mathrm{MoO}_{3}-64.0 \mathrm{~B}_{2} \mathrm{O}_{3}: 2.0 \mathrm{TiO}_{2} .
\end{aligned}
$$

The IR spectra of these glasses were recorded in the wavenumber range of $400-1600 \mathrm{~cm}^{-1}$ as shown in Figure 5. The absorption bands in the range lie from 1300 to $1400 \mathrm{~cm}^{-1}$, $1000-1200 \mathrm{~cm}^{-1}$, and another band lies at about $710 \mathrm{~cm}^{-1}$. These bands were assigned due to stretching relaxations of $\mathrm{B}-\mathrm{O}$ bonds of the trigonal $\mathrm{BO}_{3}$ units, vibrations of the $\mathrm{BO}_{4}$ structural units, and bending vibrations of $\mathrm{B}-\mathrm{O}-$ $\mathrm{B}$ linkages, respectively [107]. An absorption band near $470 \mathrm{~cm}^{-1}$ associated with vibrations of $\mathrm{PbO}_{4}$ structural units in IR spectra of all the glasses. Two new bands were observed due to $v_{1}$ and $v_{3}$ vibrational modes of $\mathrm{MoO}_{4}{ }^{2-}$ tetrahedral units near 890 and $836 \mathrm{~cm}^{-1}[108,109]$. The intensity of the absorption bands due to $\mathrm{MoO}_{4}{ }^{2-}$ tetrahedral units was observed to decrease and the band at $890 \mathrm{~cm}^{-1}$ was found to be shifted slightly towards the higher frequency side, whereas the band at $836 \mathrm{~cm}^{-1}$ was observed and to be shifted towards lower frequency with increasing the concentration 


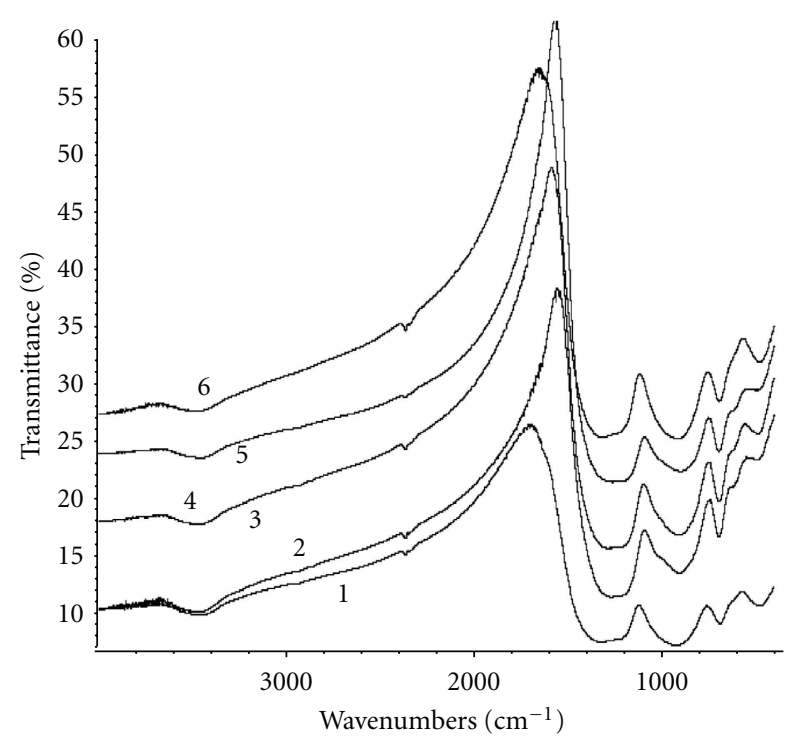

FIGURE 4: IR spectra of CdO doped lead borate $\left(x \mathrm{PbO}_{2}-(50-x) \mathrm{CdO}-\right.$ $\left.50 \mathrm{~B}_{2} \mathrm{O}_{3}\right)$ glasses $(1: x=10,2: x=15,3: x=20,4: x=25,5: x=30$, and 6: $x=35$ ) [49].

of the dopant $\mathrm{TiO}_{2}$ beyond $0.8 \mathrm{~mol} \%$. The intensity of the band associated with $\mathrm{BO}_{3}$ structural units was observed to increase at the expense of the band arising from $\mathrm{BO}_{4}$ units. The IR spectrum of glass $\mathrm{T}_{2}$ exhibited two additional prominent bands at 739 and $638 \mathrm{~cm}^{-1}$. With increasing the concentration of $\mathrm{TiO}_{2}$ up to $0.8 \mathrm{~mol} \%$, the intensity of the band at 739 was observed to increase and shifted towards low-frequency region. With further increase in the concentration of $\mathrm{TiO}_{2}$, a reversal trend in the intensity of these two bands has been observed.

2.5. Zinc Lead Borate Glasses. Motke et al. [51] reported the IR study of zinc lead borate glasses in wavenumber range of $400-4000 \mathrm{~cm}^{-1}$ (Figure 6). (A) $20 \mathrm{PbO}_{2}-30 \mathrm{ZnO}-50 \mathrm{~B}_{2} \mathrm{O}_{3}$; (B) $25 \mathrm{PbO}_{2}-25 \mathrm{ZnO}-50 \mathrm{~B}_{2} \mathrm{O}_{3}$; (C) $30 \mathrm{PbO}_{2}-20 \mathrm{ZnO}-50 \mathrm{~B}_{2} \mathrm{O}_{3}$; (D) $35 \mathrm{PbO}_{2}-15 \mathrm{ZnO}-50 \mathrm{~B}_{2} \mathrm{O}_{3}$; (E) $40 \mathrm{PbO}_{2}-10 \mathrm{ZnO}-50 \mathrm{~B}_{2} \mathrm{O}_{3}$. This study reaches to conclusion of various vibration groups which are responsible for making their structure. An absorption band at $3450 \mathrm{~cm}^{-1}$ was occurred due to $\mathrm{O}-\mathrm{H}$ stretching vibration [110-112]. The presence of structural units such as symmetric $\left(\mathrm{BO}_{3}\right)^{3-}$ triangles, $\mathrm{BO}_{4}{ }^{-}$tetrahedral, and asymmetric $\left(\mathrm{BO}_{3}\right)^{3-}$ units (i.e., nonbridging oxygen) were also confirmed in each glass samples, but $\mathrm{ZnO}$ does not affect the structure [103]. Similar vibrational studies had been also reported by Kamitsos et al., Ezz-Eldin et al., and Davis and Mott [113-115]. In these studies, it was found that the first structural group of bands lies within wavenumber range of $1200-1600 \mathrm{~cm}^{-1}$ which occurred due to the asymmetric stretching relaxation of the $\mathrm{B}-\mathrm{O}$ band of trigonal $\mathrm{BO}_{3}$ units and the vibrational group from 800 to $1200 \mathrm{~cm}^{-1}$. This vibrational group assigned is due to the $\mathrm{B}-\mathrm{O}$ bond stretching of the tetrahedral $\mathrm{BO}_{4}$ units $[116$, 117]. The third group was observed at around $700 \mathrm{~cm}^{-1}$ and is due to bending of $\mathrm{B}-\mathrm{O}-\mathrm{B}$ linkages in the borate

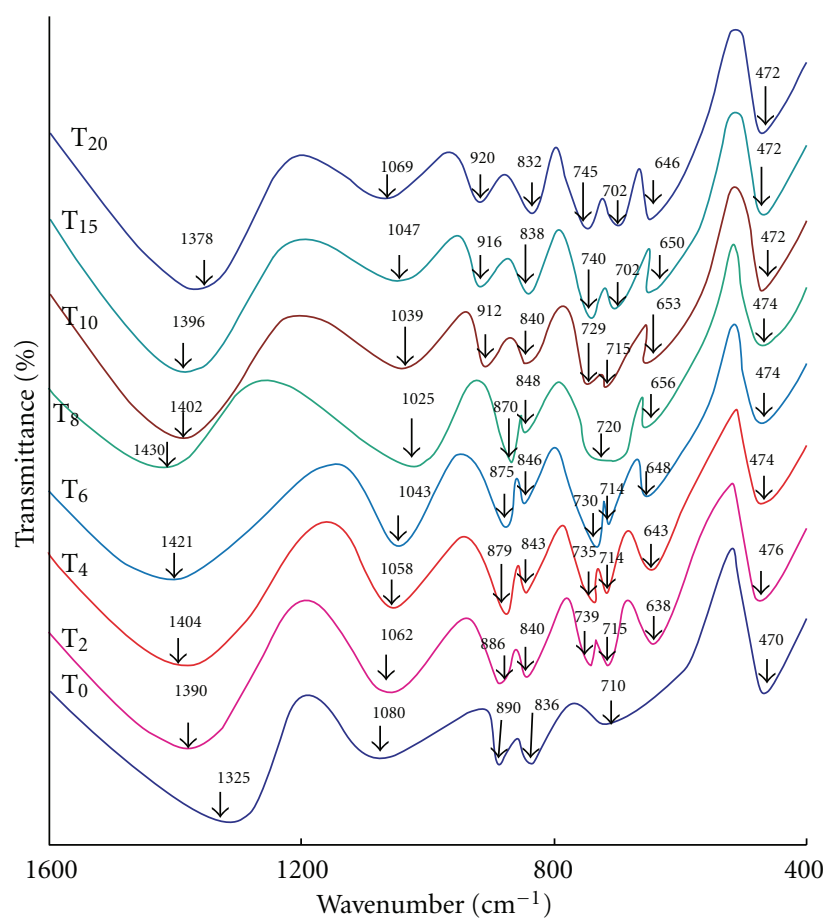

Figure 5: IR spectra of $\mathrm{PbO}-\mathrm{MoO}_{3}-\mathrm{B}_{2} \mathrm{O}_{3}: \mathrm{TiO}_{2}$ glasses [50].

networks $[118,119]$. This glass system shows the absence of boroxol ring formation. But the successive substitution of boroxol rings by triborate and tetraborate groups is observed. The pure $\mathrm{B}_{2} \mathrm{O}_{3}$ glasses consist of $\mathrm{BO}_{3}$ and $\mathrm{BO}_{4}$ groups. These groups may be attached in the form of random network. This corresponds to the progressive substitution of boroxol ring by $\mathrm{BO}_{3}$ and $\mathrm{BO}_{4}$ groups [120-122]. The absorption band near $1357 \mathrm{~cm}^{-1}$ in $40 \mathrm{~mol} \%$ glass was assigned to $\mathrm{B}-\mathrm{O}$ stretching vibrations of trigonal $\left(\mathrm{BO}_{3}\right)^{3-}$ units in metaborates, pyroborates, and orthoborates [123]. There was a change in the coordination number of boron with addition of boron trioxide to borate glasses. In these glasses, the boron is tetrahedrally surrounded by four oxygen atoms [124]. The band around $1292 \mathrm{~cm}^{-1}$ is due to $\mathrm{B}-$ $\mathrm{O}$ asymmetric stretching of $\mathrm{BO}_{3}$ unit [125], and bands around $1234 \mathrm{~cm}^{-1}$ was arisen by $\mathrm{B}-\mathrm{O}$ stretching vibrations of $\left(\mathrm{BO}_{3}\right)^{3-}$ unit in metaborate chains and orthoborates [126]. Vibrations of some boron atoms attached to nonbridging oxygen in the form of $\mathrm{BO}_{4}$ vibration were assigned band at $1004 \mathrm{~cm}^{-1}$ [36]. The formation of diborate group in present glasses had been represented by absorption around $1000 \mathrm{~cm}^{-1}$. IR spectra showed the band at about $995 \mathrm{~cm}^{-1}$ was attributed to a stretching vibration of $\mathrm{B}-\mathrm{O}-\mathrm{Si}$ linkage [82]. The absorption band is at $993 \mathrm{~cm}^{-1}$ in the IR spectra; these glasses may be attributed to a stretching vibration of $\mathrm{B}-\mathrm{O}-\mathrm{M}(\mathrm{B}-\mathrm{O}-\mathrm{Pb})$ linkage, where $\mathrm{M}$ represents a metal ion, while band at $694 \mathrm{~cm}^{-1}$ was due to combined vibrations of $\mathrm{BO}_{4}$ and $\mathrm{PbO}_{4}$ groups [83-85]. The structure of the borate glasses was also affected by the different rates of cooling of the melt and quenching temperature [127]. In $40 \mathrm{~mol} \%$ $\mathrm{PbO}$ content glass, the absorption at $616 \mathrm{~cm}^{-1}$ is due to 


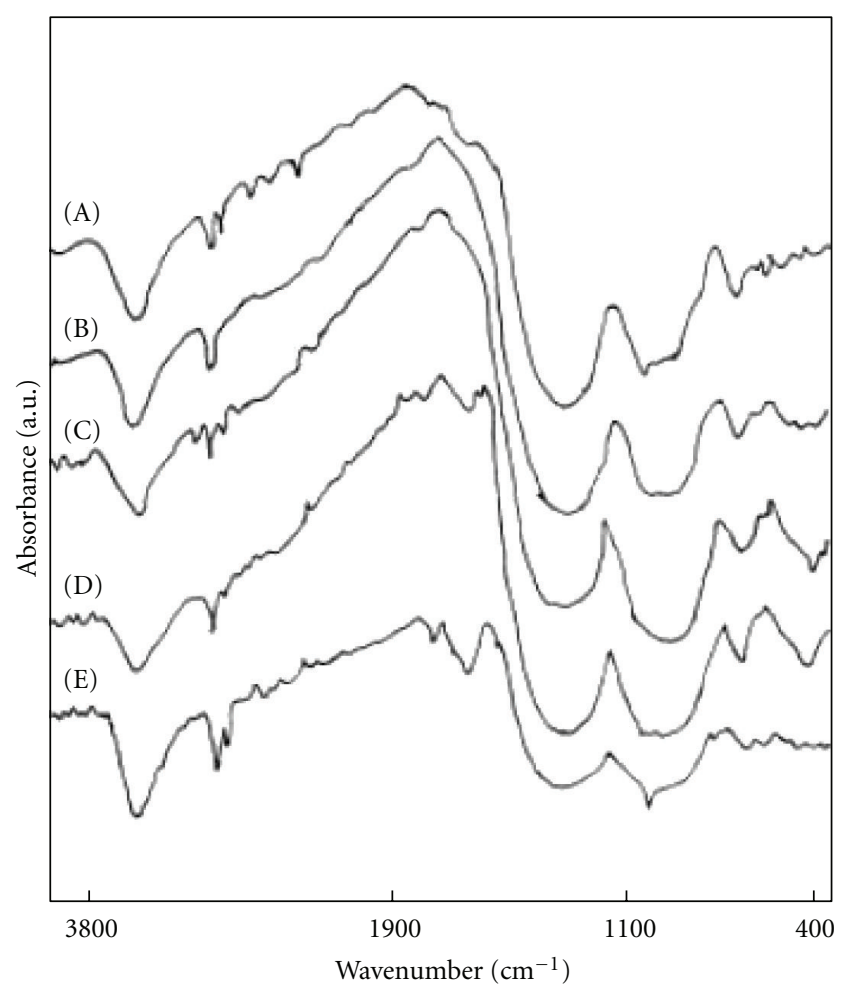

Figure 6: IR spectra of glass series $\mathrm{X} \mathrm{PbO}_{2}-(50-\mathrm{X}) \mathrm{ZnO}-$ $50 \mathrm{~B}_{2} \mathrm{O}_{3}[51]$.

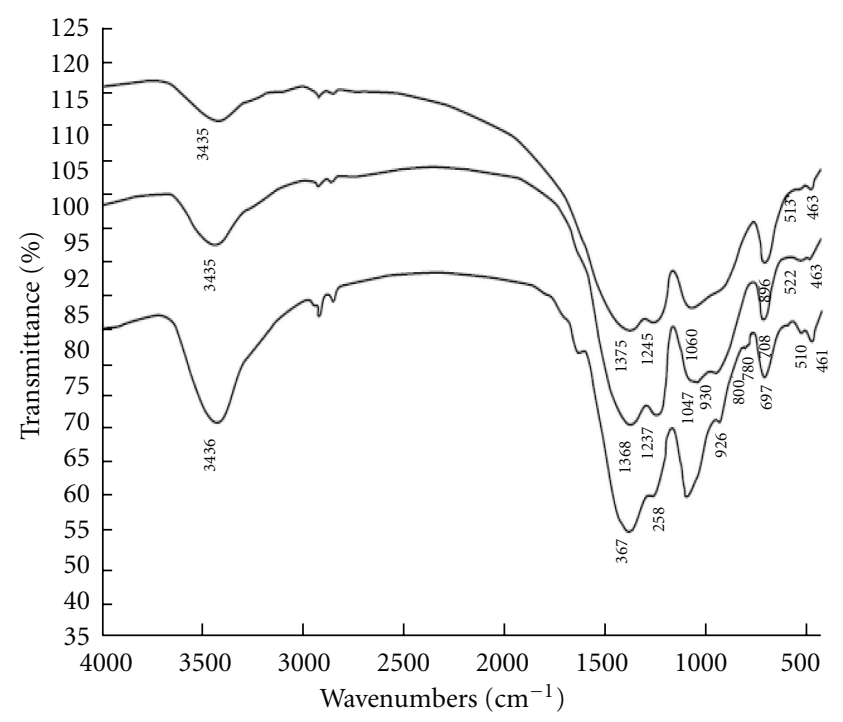

Figure 7: IR spectra of the $\mathrm{ZnO}-\mathrm{Bi}_{2} \mathrm{O}_{3}-\mathrm{B}_{2} \mathrm{O}_{3}$ glasses with $\mathrm{Bi}_{2} \mathrm{O}_{3}$ content of (1) 25 , (2) 35 , and (3) $45 \mathrm{wt} \%$ [52].

bending of $\mathrm{O}-\mathrm{B}-\mathrm{O}$. The lead plays dual role of $\mathrm{Pb}^{2+}$ cations in glass structure. First, it acts as a network modifier in the glassy matrix when these cations are ionically bonded, and secondly, if $\mathrm{Pb}-\mathrm{O}$ bond is covalent, $\mathrm{Pb}^{2+}$ cation will act as glass former [89]. Because of this dual role, lead ions may disrupt the glass network and form $\mathrm{BO}_{4}$ tetrahedral. The low-frequency bands near $453 \mathrm{~cm}^{-1}$ in IR spectra of borate

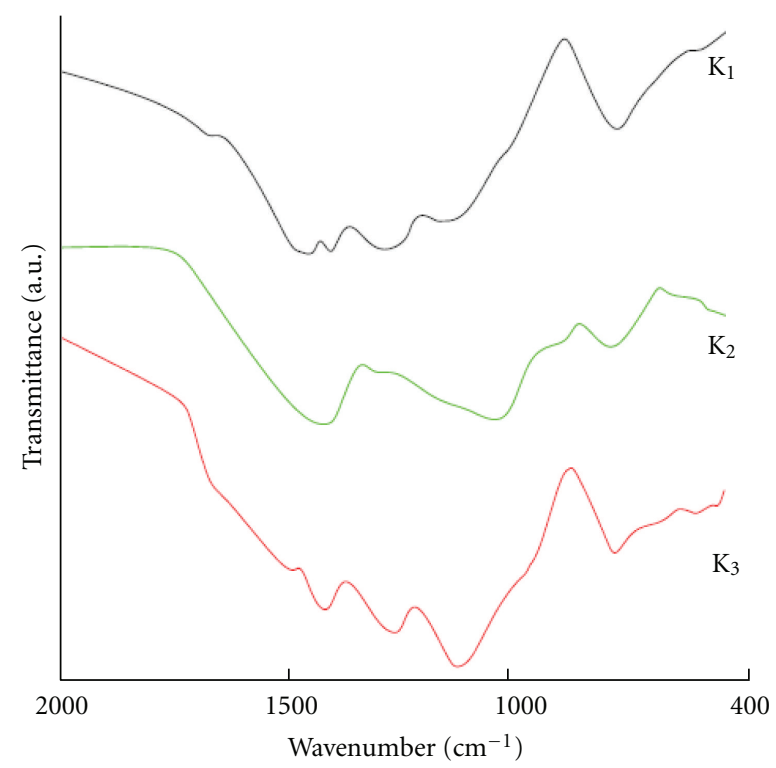

FIGURE 8: IR spectra of potassium borate glasses [53].

glasses can be attributed to vibration of metal cations such as $\mathrm{Pb}^{2+}$ or $\mathrm{Zn}^{2+}[46,91-93]$.

2.6. Bismuth Borate and Lead Bismuth Borate Glasses. Bobkova's studies on bismuth borate and lead bismuth borate glasses by IR spectroscopy show extensive report that $\mathrm{Bi}_{2} \mathrm{O}_{3}$ works as glass former, but still $\mathrm{B}_{2} \mathrm{O}_{3}$ is required for the formation of well-transparent glasses. Figure 7 shows the IR spectra of $\mathrm{ZnO}-\mathrm{Bi}_{2} \mathrm{O}_{3}-\mathrm{B}_{2} \mathrm{O}_{3}$ glasses with $\mathrm{Bi}_{2} \mathrm{O}_{3}$ in the wavenumber range of $450-4000 \mathrm{~cm}^{-1}$. A continuous network of octahedral $\left[\mathrm{BiO}_{6}\right]$ groups connected through atoms of oxygen and the high polarizability of $\mathrm{Bi}^{3+}$ cations leads to an increase in the covalent bonding between bismuth and oxygen. IR studies of pure $\gamma-\mathrm{B}_{2} \mathrm{O}_{3}$ show a broad absorption band wavenumber range of $400-550 \mathrm{~cm}^{-1}$, while the adsorption bands in the range of $150-500 \mathrm{~cm}^{-1}$ occur due to the oscillations of the $\mathrm{Bi}-\mathrm{O}$ bond. $\mathrm{BiO}_{6}, \mathrm{BiO}_{4}$ and $\mathrm{BiO}_{3}$ are the basic structural units associated in the bismuth borate glasses, but most widely $\mathrm{BiO}_{6}$ group was found in these glasses [128-131].

2.7. Potassium Borate Glasses. The structural information in potassium borate glasses was extensively studied by Singh et al. [53]. This study of these glass systems gives the information not only about structure, but also about the coordination number of the compound with respect to oxygen, network formers, and change in oxygen bonds of the framework which also is induced by the cations modifiers $[132,133]$. IR studies of potassium borate glasses in the wavenumber range of $450-2000 \mathrm{~cm}^{-1}$ are shown in the Figure 8. Due to small mass as other network forming elements, the main vibrational modes associated with the glass network appear well above $500 \mathrm{~cm}^{-1}$ (in the mid-infrared region), and these networking modes are well separated from the metal ion site vibrational modes which are active 


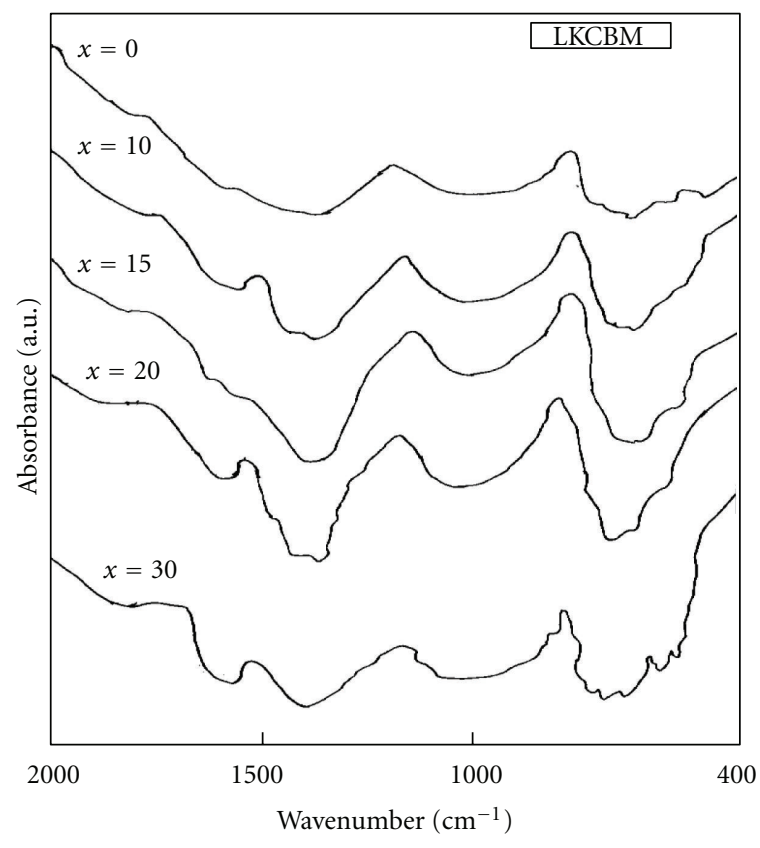

Figure 9: IR transmission spectra of LKCBM glasses [54].

in the far infrared region [94-96]. Boron has an ability to change its coordination number with oxygen between three and four providing a range of anionic environment that can coordinate the modifying metal ions. The main IRabsorption peaks in $\mathrm{B}_{2} \mathrm{O}_{3}$ containing glasses lie at different wavenumbers of 710,1260 , and $1420 \mathrm{~cm}^{-1}$. The absorption peak near $1420 \mathrm{~cm}^{-1}$ occurred due to the ring stretching of the boroxol groups, and the $1260 \mathrm{~cm}^{-1}$ vibration is due to the $\mathrm{B}-\mathrm{O}-\mathrm{B}$ bond constituting the linkage of boroxol groups to neighbouring groups [134]. The absorption bands near 680 and $1350 \mathrm{~cm}^{-1}$ can be attributed to bending vibrations of $\mathrm{BO}_{3}$ triangles and stretching vibrations of $\mathrm{BO}_{3}$ units with nonbridging oxygens (NBOs), respectively [135-138]. The band near $1066 \mathrm{~cm}^{-1}$ was observed due to $\mathrm{B}-\mathrm{O}$ bond stretching vibrations from triborate, tetraborate, and pentaborate groups. This indicates that there is a formation of fourcoordinated boron units with the addition of heavy metal oxide. The broad absorption peaks at around $1210 \mathrm{~cm}^{-1}$ can be attributed to asymmetric stretching vibrations of $\mathrm{B}-\mathrm{O}$ bond in metaborates, pyroborates, and orthoborates. With the addition of fly ash, potassium borate glasses give significant change in their IR spectra. A prominent band at $950 \mathrm{~cm}^{-1}$ attributed to the stretching vibrations of $\mathrm{B}-\mathrm{O}-\mathrm{Si}$ linkage, as the main content of fly ash is silica. A shoulder band at $816 \mathrm{~cm}^{-1}$ can be assigned due to combined effect of stretching vibrations of $\mathrm{Si}-\mathrm{O}-\mathrm{Si}$ and $\mathrm{B}-\mathrm{O}-\mathrm{B}$ network [87].

2.8. Lithium-Potassium Borate Glasses. IR studies of lithiumpotassium borate glass system $(30-x) \mathrm{Li}_{2} \mathrm{O}-x \mathrm{~K}_{2} \mathrm{O}-10 \mathrm{CdO}-$ $59 \mathrm{~B}_{2} \mathrm{O}_{3}(x=0,10,15,20$, and 30$)$ doped with $1 \mathrm{MnO}_{2}$ in the wavenumber range of $400-2000 \mathrm{~cm}^{-1}$ show different transmission bands at different wavenumber positions (Figure 9). When glass sample was radiated with IR radiation, then portions of the incident radiation are absorbed at particular wavelengths. This characterizes the functional groups comprising the molecule and the overall configuration of the atoms as well. The IR transmission spectra of LKCBM glasses are given in Figure 9. IR spectra of these glasses show a band in the range of $400-1600 \mathrm{~cm}^{-1}$. The band in the wavenumber range of $400-780 \mathrm{~cm}^{-1}$ was formed due to the bending vibrations of various borate arrangements, vibrations of $\mathrm{Li}$ cations through glass network, and deformation modes of network structures as well as vibrations of some $\mathrm{MnO}_{4}$ groups $[36,54,139,140]$. The spectral band in the region $780-1100 \mathrm{~cm}^{-1}$ is due to the $\mathrm{B}-\mathrm{O}$ asymmetric stretching of tetrahedral $\mathrm{BO}_{4}$ units and vibrations of diborates bridging to pentaborate groups; while the dominating transmission bands in the range of $1100-1600 \mathrm{~cm}^{-1}$ were assigned due to the stretching vibrations of borate units in which boron atoms are connected to the three oxygens $\left(\mathrm{BO}_{3}\right.$ and $\mathrm{B}_{3} \mathrm{O}_{6}$ units) $[141,142]$. Recently, Aboud et al. reported the IR studies of these glasses in the wavenumber range of $600-2000 \mathrm{~cm}^{-1}$ as shown in Figure 10. The compositional distribution and assignment of IR spectra have been listed in Table 3 [55]. In this study, it was observed that the vibrational modes of the borate network are mainly active in three infrared spectral regions from 1200 to $1500 \mathrm{~cm}^{-1}$ (B$\mathrm{O}$ stretching of trigonal $\mathrm{BO}_{3}{ }^{-}$units), from 800 to $1200 \mathrm{~cm}^{-1}$ (B-O stretching of tetrahedral $\mathrm{BO}_{4}{ }^{-}$units), and from 600 to $800 \mathrm{~cm}^{-1}$ (bending vibrations of various borate segments).

2.9. Zinc and Manganese-Doped Borate Glasses. The vibration spectra of the zinc and manganese oxides containing borate glasses were obtained using $\mathrm{KBr}$ pellet technique in the range of $400-4000 \mathrm{~cm}^{-1}$. FTIR spectrum of manganese oxides containing borate glasses is shown in Figure 11. IR spectra exhibit broad absorption bands as a consequence of the general disorder in the network, mainly due to a wide distribution of structural units occurring in these glasses. The band in low wavenumber side marked as " $\mathrm{A}$ " attributed to the presence of transition metal ions in bivalent state $\left(\mathrm{Zn}^{2+}, \mathrm{Mn}^{2+}\right)$. The absorption bands marked as "B," "C" and " $\mathrm{D}$ " are due to borate matrix. Details classifications of the appeared peaks have been presented in Table 4. The absorption peak near $700 \mathrm{~cm}^{-1}$ was assigned due to bending of $\mathrm{B}-\mathrm{O}-\mathrm{B}$ linkage, and peaks about at $1020 \mathrm{~cm}^{-1}$ were occurred due to $\mathrm{B}-\mathrm{O}$ stretching of $\mathrm{BO}_{4}$ tetrahedra, while peaks at wavenumber $1280 \mathrm{~cm}^{-1}$ attributed to asymmetric stretching of $\mathrm{B}-\mathrm{O}$ of trigonal $\mathrm{BO}_{3}$. Absence of peak around $806 \mathrm{~cm}^{-1}$ indicates that borate network does not contain any boroxol ring. Generally, in pure $\mathrm{B}_{2} \mathrm{O}_{3}$ glass, most of the boron is involved in $\mathrm{B}_{3} \mathrm{O}_{6}$ boroxol rings [143-145]. The addition of transition metal ion breaks these rings, and increasingly $\mathrm{BO}_{3}$ and $\mathrm{BO}_{4}$ units are formed, which is reflected in Inset: magnified version of FTIR curves to prove the absence of boroxol rings our samples also [97].

2.10. Lead Strontium Titanate Borosilicate Glasses. IR study of lead strontium titanate borosilicate glasses in glass system $\left[\left(\mathrm{Pb}_{x} \mathrm{Sr}_{1-x}\right) \mathrm{TiO}_{3}\right]-\left[2 \mathrm{SiO}_{2} \cdot \mathrm{B}_{2} \mathrm{O}_{3}\right]-\left[\mathrm{BaO} \cdot \mathrm{K}_{2} \mathrm{O}\right]-\left[\mathrm{La}_{2} \mathrm{O}_{3}\right]$ was studied by Srivastava [62] and Gautam et al. [63]. Five letters 


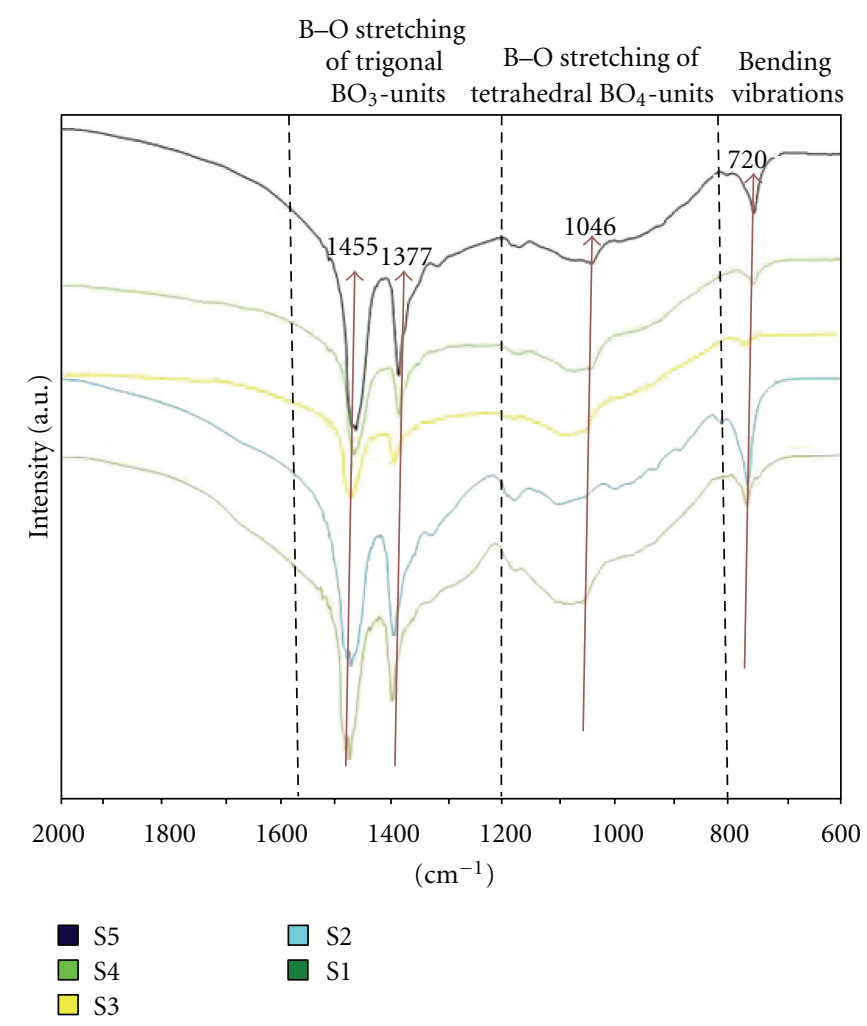

FIgURE 10: FTIR spectra of lithium potassium borate glasses [55].

TABLE 3: The FTIR peaks positions of the $(90-x) \mathrm{H}_{2} \mathrm{BO}_{3}-x \mathrm{Li}_{2} \mathrm{CO}_{3}-10 \mathrm{~K}_{2} \mathrm{CO}_{3}$ glasses system [55].

\begin{tabular}{|c|c|c|c|c|c|c|}
\hline \multirow{2}{*}{ Sample number } & \multicolumn{4}{|c|}{ Composition (mol\%) } & \multicolumn{2}{|c|}{ Absorption peak $\left(\mathrm{cm}^{-1}\right)$} \\
\hline & $\mathrm{H}_{3} \mathrm{BO}_{3}$ & $\mathrm{Li}_{2} \mathrm{CO}_{3}$ & $\mathrm{~K}_{2} \mathrm{CO}_{3}$ & $\begin{array}{c}\mathrm{B}-\mathrm{O} \text { stretching of trigonal } \\
\mathrm{BO}_{3}^{-} \text {units }\end{array}$ & $\begin{array}{l}\mathrm{B}-\mathrm{O} \text { stretching of } \\
\text { tetrahedral } \mathrm{BO}_{4}^{-} \text {units }\end{array}$ & Bending vibrations \\
\hline S1 & 80 & 10 & 10 & $1455-1377$ & 1046 & 720 \\
\hline S2 & 75 & 15 & 10 & $1455-1377$ & 1046 & 720 \\
\hline S3 & 70 & 20 & 10 & $1455-1377$ & 1046 & 722 \\
\hline S4 & 65 & 25 & 10 & $1458-1376$ & 1045 & 722 \\
\hline S5 & 60 & 30 & 10 & $1455-1376$ & 1045 & 720 \\
\hline
\end{tabular}

TABLE 4: Various absorption peak positions obtained from FTIR spectra [61].

\begin{tabular}{lcl}
\hline Band & Position of Band $\left(\mathrm{cm}^{-1}\right)$ & Assignment \\
\hline A & 425 & $\begin{array}{l}\text { Vibration of metal cations } \\
\text { such as } \mathrm{Zn}^{2+} / \mathrm{Mn}^{2+}\end{array}$ \\
B & 700 & $\begin{array}{l}\text { Bending of } \mathrm{B}-\mathrm{O}-\mathrm{B} \text { linkages } \\
\text { B-O stretching of } \mathrm{BO}_{4} \\
\text { tetrahedra }\end{array}$ \\
C & 1020 & $\begin{array}{l}\text { Asymmetric stretching of } \\
\text { B-O of trigonal } \mathrm{BO}_{3}\end{array}$ \\
D & 1280 &
\end{tabular}

glass code refers to the composition of the glass. First two letters PT, 9P, and so forth designate the fraction of lead, that is, $x$ in the glass. PT refers to $x=1.0$, that is, $100 \%$ lead $(\mathrm{Pb})$ and $0 \%$ strontium. $9 \mathrm{P}, 8 \mathrm{P}$, and so forth, refer to $x=0.9,0.8$, respectively. The third letter $\mathrm{L}$ indicates that $\mathrm{La}_{2} \mathrm{O}_{3}$ is used as an additive. The last two letters $5 \mathrm{~B}$ refer to fraction of modifier oxides $\mathrm{BaO}$ in the parent glass compositions. These spectra consist of broad and sharp bands in different regions of $400-4000 \mathrm{~cm}^{-1}$ as shown in Figures 12 and 13. The compositional changes in IR spectra are strongly influenced. These IR spectra of these glasses show ten absorption peaks. Absorption peaks in the range of $3425-3501 \mathrm{~cm}^{-1}$ are attributed to stretching of $-\mathrm{OH}^{-}$bond inside the glassy network, and it form at nonbridging oxygen sites. Two absorption bands in the range of $1200-1750 \mathrm{~cm}^{-1}$ were found in all the glass samples. A single-broad absorption peak was observed in the glass lead rich glass composition, while the same peak splitted into two peaks in all Sr rich glass compositions. These spectral bands were observed due to the vibrational mode of the borate network, and these vibrational modes of the 
TABLE 5: Wavelengths of different absorption peaks in FTIR spectra of the glasses in the system $\left[\left(\mathrm{Pb}_{x} \mathrm{Sr}_{1-x}\right) \mathrm{TiO}_{3}\right]-\left[2 \mathrm{SiO}_{2} \cdot \mathrm{B}_{2} \mathrm{O}_{3}\right]-\left[\mathrm{BaO} \cdot \mathrm{K}_{2} \mathrm{O}\right]-$ $\left[\mathrm{La}_{2} \mathrm{O}_{3}\right][62]$.

\begin{tabular}{|c|c|c|c|c|c|c|c|c|c|c|c|c|c|c|c|c|}
\hline \multirow{3}{*}{$\begin{array}{l}\text { Glass } \\
\text { codes }\end{array}$} & \multirow{3}{*}{$x$} & \multicolumn{15}{|c|}{ Wave length of different absorption peaks $\left(\mathrm{cm}^{-1}\right)$} \\
\hline & & \multirow[t]{2}{*}{1} & \multicolumn{2}{|c|}{2} & \multicolumn{2}{|c|}{3} & \multirow[t]{2}{*}{4} & \multirow[t]{2}{*}{5} & \multirow[t]{2}{*}{6} & \multirow{2}{*}{\multicolumn{2}{|c|}{7}} & \multicolumn{2}{|c|}{8} & 9 & \multicolumn{2}{|c|}{10} \\
\hline & & & a & $\mathrm{b}$ & a & b & & & & & & & $\mathrm{b}$ & & a & $\mathrm{b}$ \\
\hline PTL5B & 1.0 & 3483 & 2915 & 2890 & \multicolumn{2}{|c|}{ - } & 1730 & 1650 & - & \multicolumn{2}{|c|}{1280} & \multicolumn{2}{|c|}{995} & 715 & \multicolumn{2}{|c|}{420} \\
\hline 9PL5B & 0.9 & 3472 & 2991 & 2860 & \multicolumn{2}{|c|}{ - } & 1730 & 1630 & - & \multicolumn{2}{|c|}{1250} & 10 & & 725 & \multicolumn{2}{|c|}{430} \\
\hline 8PL5B & 0.8 & 3500 & 2990 & 2890 & \multicolumn{2}{|c|}{ - } & 1730 & 1630 & - & \multicolumn{2}{|c|}{1290} & 99 & & 730 & \multicolumn{2}{|c|}{450} \\
\hline 7PL5B & 0.7 & 3480 & 2925 & 2865 & \multicolumn{2}{|c|}{-} & 1750 & 1645 & - & \multicolumn{2}{|c|}{1300} & 99 & & 705 & \multicolumn{2}{|c|}{460} \\
\hline 6PL5B & 0.6 & 3490 & 2915 & 2840 & \multicolumn{2}{|c|}{-} & 1740 & 1638 & - & \multicolumn{2}{|c|}{1230} & 99 & & 701 & \multicolumn{2}{|c|}{480} \\
\hline 5PL5B & 0.5 & 3450 & 2925 & 2840 & 2410 & 2290 & 1740 & 1640 & - & 1310 & 1210 & 10 & & 703 & 550 & 480 \\
\hline 4PL5B & 0.4 & 3485 & 2940 & 2850 & 2420 & 2300 & 1740 & 1650 & 1575 & 1340 & 1210 & 1030 & 940 & 703 & 550 & 480 \\
\hline 3PL5B & 0.3 & 3500 & 2922 & 2850 & 2500 & 2300 & 1750 & 1680 & - & 1375 & 1225 & 1000 & 960 & 720 & 555 & 440 \\
\hline
\end{tabular}

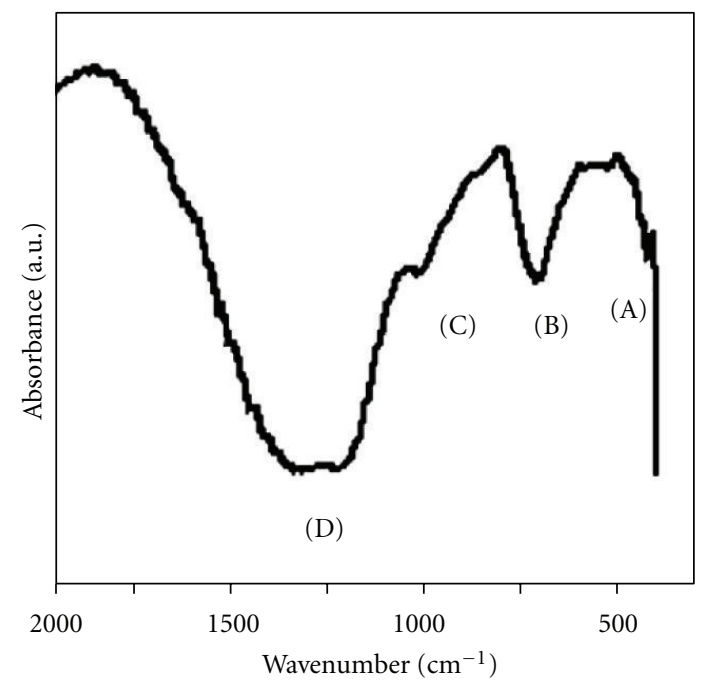

FIGURE 11: FTIR spectra of zinc manganese borate glasses for $50 \mathrm{~mol} \% \mathrm{~B}_{2} \mathrm{O}_{3}[61]$.

borate network are mainly due to the asymmetric stretching relaxation of the $\mathrm{B}-\mathrm{O}$ bond of trigonal $\mathrm{BO}_{3}$ units. These vibrational modes occur at $1200-1600 \mathrm{~cm}^{-1}$. The bands at around $1000 \mathrm{~cm}^{-1}$ are attributed to a stretching vibration of B-O-Si linkage. A broad absorption peak lies between 685 and $709 \mathrm{~cm}^{-1}$ and was due to the bending of $\mathrm{B}-\mathrm{O}-\mathrm{B}$ linkages in the borate glassy network $[86,146]$. The low-frequency bands in the IR spectra of these glasses can be attributed to vibration of metal cation such as $\mathrm{Pb}^{2+}$ and was attributed to the vibrations of $\mathrm{Pb}^{2+}$ cations. Absorption peaks in FTIR spectra of the $(\mathrm{Pb} \mathrm{Sr}) \mathrm{TiO}_{3}$ borosilicate glasses have been listed in Table 5.

2.11. Barium Strontium Titanate Borosilicate Glasses. More recently, our research group reported the IR studies of barium strontium titanate borosilicate glasses in wavenumber range of $450-4000 \mathrm{~cm}^{-1}$ and shown in Figure 14. The first sharp and broad absorption peak at $3440 \mathrm{~cm}^{-1}$ was assigned due to stretching mode of $\mathrm{O}-\mathrm{H}$ bonds inside the glassy network [64]. These $\mathrm{O}-\mathrm{H}$ bond groups are formed at nonbridging oxygen sites. An absorption band at wavenumber $2372 \mathrm{~cm}^{-1}$ (peak no. 2) was observed in the IR spectra. IR spectra show a sharp absorption at $1632 \mathrm{~cm}^{-1}$ (peak no. 3). A doublet absorption band occurs at wavenumbers 1351$1398 \mathrm{~cm}^{-1}$ (peak no. $4 \mathrm{a}, \mathrm{b}$ ). The absorption peak no. 5 was observed at wavenumber $1276 \mathrm{~cm}^{-1}$. These absorption bands occurred due to the vibrational mode of the borate network in borate containing glass systems and asymmetric stretching relaxation of the $\mathrm{B}-\mathrm{O}$ bonds of trigonal $\mathrm{BO}_{3}$ units. This band lies between wavenumber range of $1200-1750 \mathrm{~cm}^{-1}$ $[80,81]$. An absorption peak at $1025 \mathrm{~cm}^{-1}$ is attributed to stretching vibrations of $\mathrm{B}-\mathrm{O}-\mathrm{Si}$ linkage. Absorption band at $714 \mathrm{~cm}^{-1}$ occurred due to the diborate linkage of $\mathrm{B}-\mathrm{O}-\mathrm{B}$, in the borate glassy network. In this linkage, both boron atoms are tetrahedrally coordinated with triborate superstructural units. An absorption peak at $519 \mathrm{~cm}^{-1}$ at low wavenumber side was also observed due to vibration of metal cation such as $\mathrm{Ba}^{2+}$ and $\mathrm{Sr}^{2+}$.

2.12. Sodium Borosilicate Glasses. IR studies of sodium borosilicate glasses show various absorption bands in the wavenumber ranges of $400-2000 \mathrm{~cm}^{-1}$; it has been given in the Figures 15 and 16 . The bands near $900-1100 \mathrm{~cm}^{-1}$ dominate over all bands. The absorption band around $970 \mathrm{~cm}^{-1}$ and a line near $1065 \mathrm{~cm}^{-1}$ were identified. Three additional weaker bands peaking near 460,780 , and $1420 \mathrm{~cm}^{-1}$ can be identified in the IR spectrum. When $\mathrm{Ca}$ and $\mathrm{Ba}$ are substituted for sodium, the shape of the dominant absorption band changes, and the band peak shifts into the highfrequency side [65]. In addition, the intensity of the band peaking at $1420 \mathrm{~cm}^{-1}$ increases, while a small bands near $715 \mathrm{~cm}^{-1}$ and $780 \mathrm{~cm}^{-1}$ shifts by approximately $20 \mathrm{~cm}^{-1}$ into the high-frequency region. The low-frequency sideband peaking near $460 \mathrm{~cm}^{-1}$ is due to deformation vibrations of the Si-O-Si bridges, and bands in the region of 780 $800 \mathrm{~cm}^{-1}$ were formed due to deformation vibrations of the $\mathrm{Si}-\mathrm{O}-$ end groupings, while the band near $970 \mathrm{~cm}^{-1}$ attests to the presence of $\mathrm{BO}_{4}$ tetrahedra in the structure of the glass [147]. The band at $1065 \mathrm{~cm}^{-1}$ IR spectra of the sodium glass is related with the asymmetric stretching vibrations of the 


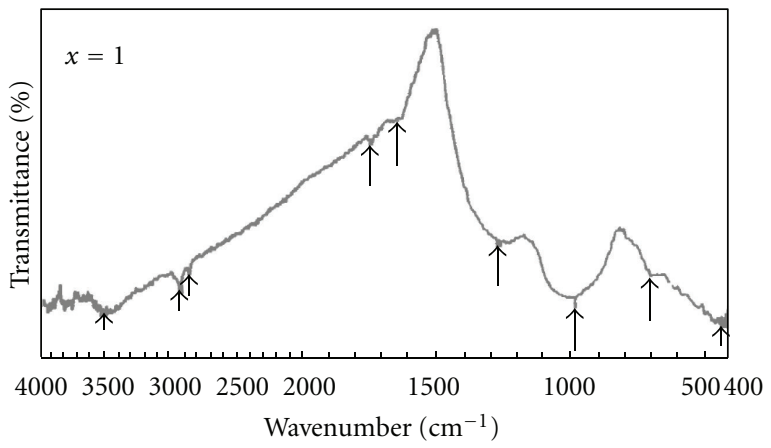

(a)

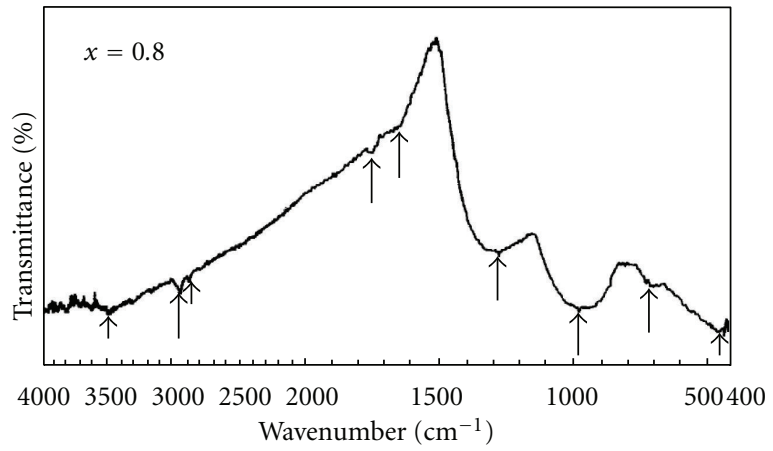

(c)

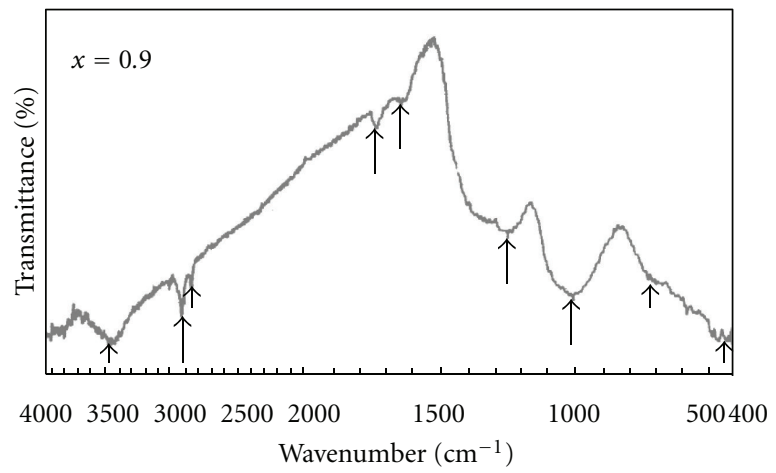

(b)

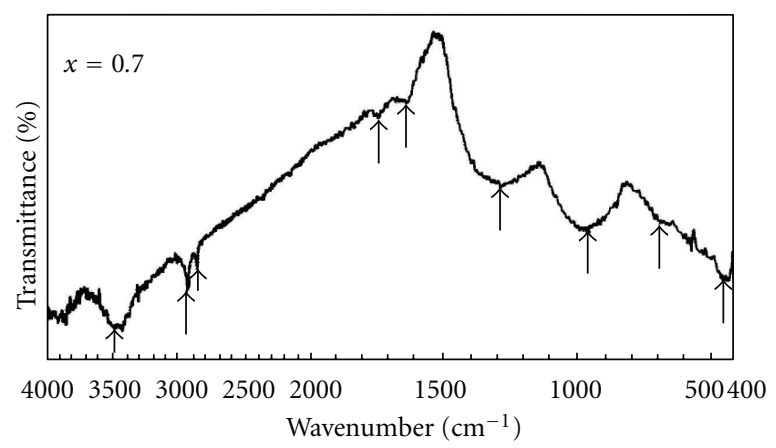

(d)

Figure 12: Infrared spectra of glasses (a) PTL5B, $x=1.0$, (b) 9PL5B, $x=0.9$, (c) 8PL5B, $x=0.8$, and (d) 7PL5B, $x=0.7$ [62, 63].

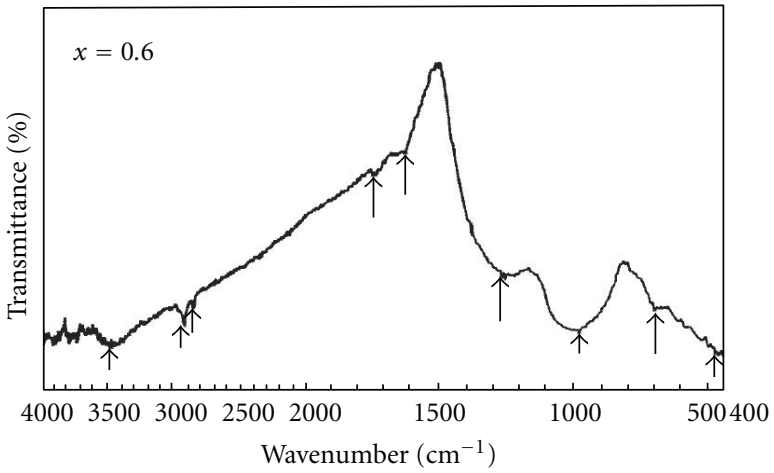

(a)

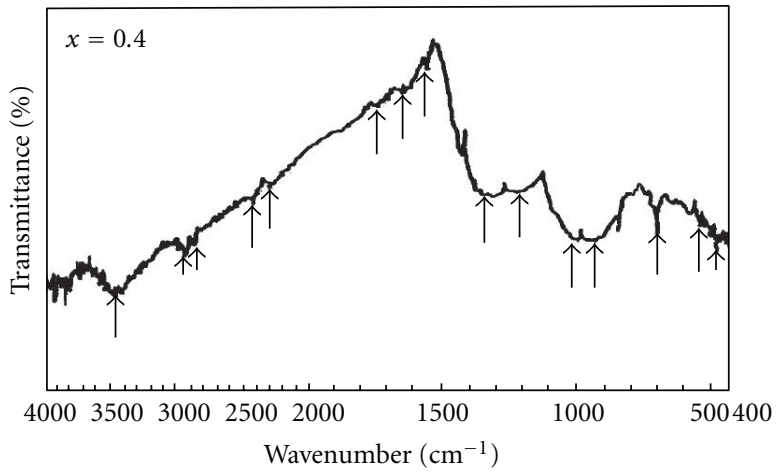

(c)

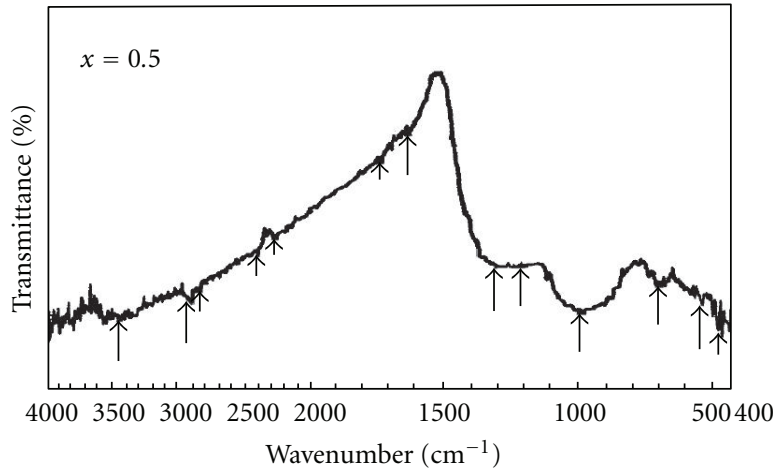

(b)

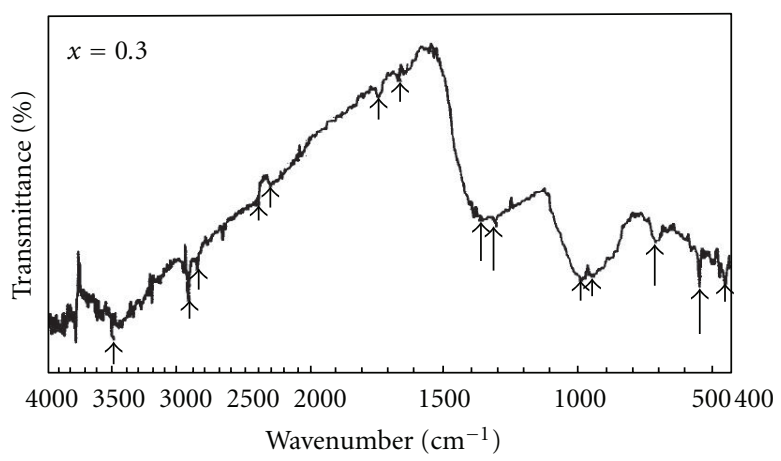

(d)

Figure 13: Infrared spectra of glasses (a) 6PL5B, $x=0.6$, (b) 5PL5B, $x=0.5$, (c) 4PL5B, $x=0.4$, and (d) 3PL5B, $x=0.3$ [62, 63]. 


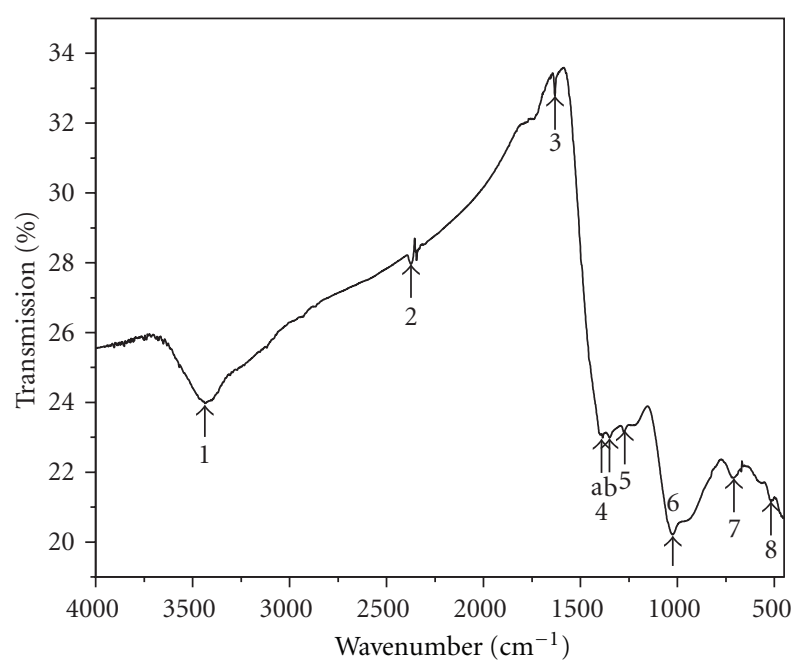

FIGURE 14: IR studies of barium strontium titanate borosilicate glasses [64].

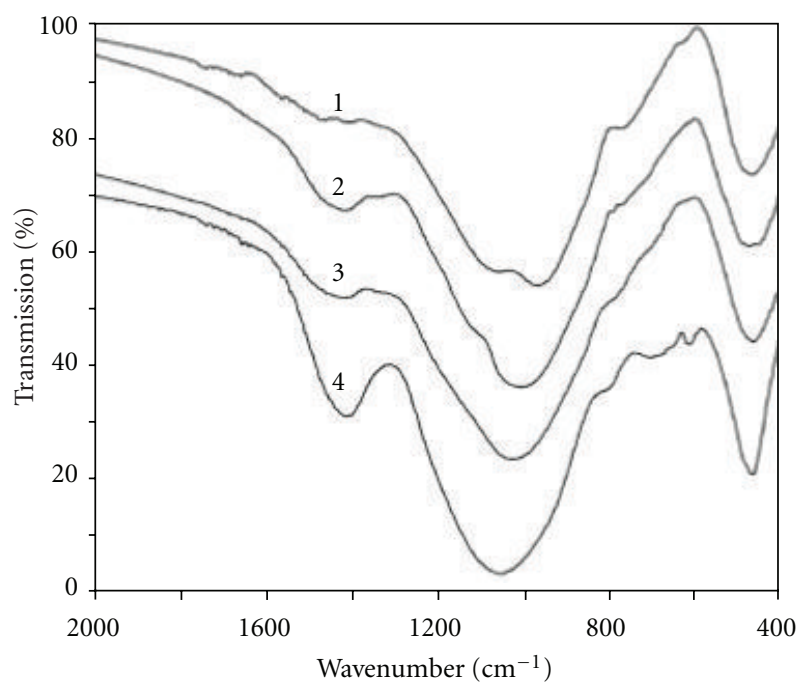

FIGURE 15: IR spectra of calcium containing sodium borosilicate glasses [65].

$\mathrm{Si}-\mathrm{O}-\mathrm{Si}$ bonds, and the shift of its peak is due to a change of the degree of polymerization of the glass structure [148]. The absorption bands near 715 and $1420 \mathrm{~cm}^{-1}$ are associated with different vibrational modes of the planar $\mathrm{BO}_{3}$ triangles [36].

2.13. Lead Bismuth Borosilicate Glasses. The IR studies of lead bismuth borate glasses had been reported by Chen et al. and shown in Figure 17. The glass compositions have been given as PBB01(50-40-10), PBB2 (40-50-10), PBB03 (20-7010), PBB4 (35-45-20), PBB5 (15-65-20), and PBB06 (25-3540). This absorption band occurs due to stretching mode of $\mathrm{O}-\mathrm{H}$ bonds inside the glassy network. With addition of lead oxide, the band shifted towards higher wavenumber side. An absorption band between wavenumber 2867 and $2943 \mathrm{~cm}^{-1}$, and it occurs due to hydrogen bonding [81].

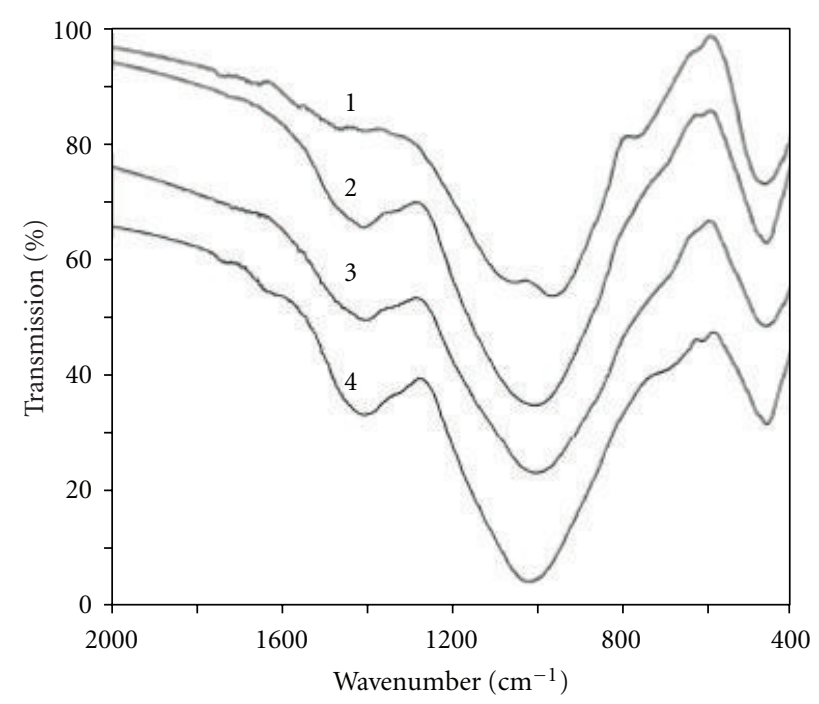

FIGURE 16: IR spectra of barium containing sodium borosilicate glasses [65].

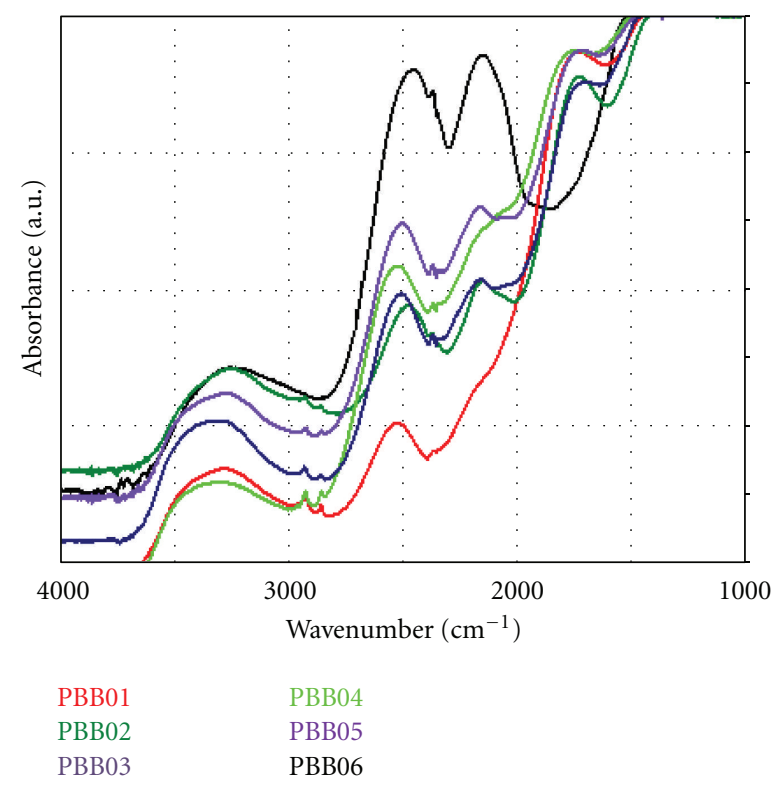

Figure 17: IR spectra of $\mathrm{PbO}-\mathrm{Bi}_{2} \mathrm{O}_{3}-\mathrm{B}_{2} \mathrm{O}_{3}$ glass samples [66].

This absorption band disappears in IR spectra when lead content increased to $40 \%$. The vibrational mode of the borate network exhibited an absorption band between wavenumbers 1522 and $1483 \mathrm{~cm}^{-1}$ due to the asymmetric stretching relaxation in $\mathrm{B}-\mathrm{O}$ bonds of trigonal $\mathrm{BO}_{3}$ units. Such types of vibrational modes occur within the wavenumbers range of $1200-1750 \mathrm{~cm}^{-1}[88]$. The broad absorption band at around $1120-1153 \mathrm{~cm}^{-1}$ was occurred due to a stretching vibration of B-O-Si linkage [149]. IR spectra of all glass samples exhibited an absorption band within the wavenumber range of $816-833 \mathrm{~cm}^{-1}$ due to the diborate linkage, $\mathrm{B}-\mathrm{O}-\mathrm{B}$, in the borate glassy network. In this linkage, both boron atoms are tetrahedrally coordinated with triborate superstructural units [150]. An absorption peaks at lower wavenumber 
Table 6: Assignment of infrared bands in the spectra.

\begin{tabular}{|c|c|c|}
\hline $\begin{array}{l}\text { Peak Positions } \\
\left(\mathrm{cm}^{-1}\right)\end{array}$ & IR Assignments & References \\
\hline $3600-3750$ & OH group & {$[70,71]$} \\
\hline $3200-3500$ & Molecular water & {$[70,71,77-79]$} \\
\hline $2700-3000$ & Hydrogen bonding & {$[36]$} \\
\hline $1200-1750$ & $\begin{array}{c}\text { Asymmetric stretching relaxation of } \mathrm{B}-\mathrm{O} \text { bonds of trigonal } \mathrm{BO}_{3} \text { units } \\
\text { Detailed Classification of group 1200-1750 }\end{array}$ & \multirow{4}{*}{$\begin{array}{l}{[57-59,64,74-} \\
\quad 76,80,81]\end{array}$} \\
\hline $\begin{array}{l}\sim 1480 \\
\sim 1345\end{array}$ & $\begin{array}{l}\text { Asymmetric stretching modes of borate triangles } \mathrm{BO}_{3} \text { units } \\
\text { Presence of pyroborate, orthoborate groups containing } \mathrm{BO}_{3}{ }^{-}\end{array}$ & \\
\hline $1200-1300$ & $\mathrm{~B}-\mathrm{O}$ bond stretching vibrations and $\mathrm{B}-\mathrm{O}$ bridging between $\mathrm{B}_{3} \mathrm{O}_{6}$ and $\mathrm{BO}_{3}$ triangles & \\
\hline$\sim 1235$ & Asymmetric stretching vibrations of $\mathrm{B}-\mathrm{O}$ bonds from orthoborate groups & \\
\hline $700-1200$ & $\begin{array}{l}\text { Composite of two silicate chains and borate phases } \\
\qquad \text { Detailed Classification of groups 700-1200 }\end{array}$ & \\
\hline$\sim 1015$ & Pentaborate group & \\
\hline 992 & B-O-M, M means metal ion & \\
\hline$\sim 965$ & B-O-B linkages & \\
\hline $950-1050$ & Stretching vibrations of B-O-Si linkage & $\begin{array}{l}{[38,39,49,60} \\
63,67,68,82 \\
88]\end{array}$ \\
\hline$\sim 875$ & Stretching vibrations of tetrahedral $\mathrm{BO}_{4}{ }^{-}$units & \\
\hline $816-833$ & Diborate linkage, $\mathrm{B}-\mathrm{O}-\mathrm{B}$ networks & \\
\hline$\sim 815$ & Si-O-Si network & \\
\hline 806 & Boroxol rings & \\
\hline 760 & $\mathrm{BO}_{3}-\mathrm{O}-\mathrm{BO}_{4}$ bond-bending vibrations & \\
\hline 700 & Bending of $\mathrm{B}-\mathrm{O}-\mathrm{B}$ linkage & \\
\hline$\sim 694$ & Combined vibrations of $\mathrm{BO}_{4}$ and $\mathrm{PbO}_{4}$ groups & {$[83-85]$} \\
\hline 680 & $\mathrm{~B}-\mathrm{O}-\mathrm{B}$ bond-bending vibrations from pentaborate group or bending vibrations of $\mathrm{BO}_{3}$ triangles & {$[80]$} \\
\hline$\sim 616$ & Bending of $\mathrm{O}-\mathrm{B}-\mathrm{O}$ & [89] \\
\hline$<600$ & $\mathrm{~Pb}^{2+}, \mathrm{Zn}^{2+}, \mathrm{Mn}^{2+}, \mathrm{Bi}^{3+}, \mathrm{Li}^{+}$, and $\mathrm{Ba}^{2+}$ or any metallic cations & {$[55,80,90-97]$} \\
\hline
\end{tabular}

side attributed to vibration of metal cation such as $\mathrm{Pb}^{2+}$ and $\mathrm{Bi}^{3+}$. The assignment of various vibrations groups in IR spectra have been listed in Table 6. FTIR spectra of these glasses many absorption bands at different wavelengths region which may attributed attribute to $\mathrm{OH}$-group and other borate groups. PBB01 showed more than 70\% of transmittance from $2000 \mathrm{~nm}$ to $4000 \mathrm{~nm}$. The peak around $3300 \mathrm{~nm}$ is due to the $\mathrm{OH}$ absorption. With the increase of $\mathrm{PbO}$ and $\mathrm{Bi}_{2} \mathrm{O}_{3}$ content, the spectrum exhibits a shift to longer wavelength [66].

\section{Summary}

In this paper, we have discussed the infrared spectroscopy of borate glasses and the effects of various additives on structural properties of these glasses. The borate glasses contain the molecular water, hydroxyl group along with hydrogen bonding which was confirmed by absorption bands in wavenumber range of $2700-3750 \mathrm{~cm}^{-1}$ in the IR spectra of these glasses. The amount of molecular water content affected with variation of different metallic additives. $10-20 \mathrm{~mol} \%$ addition of $\mathrm{PbO}$ does not affect the borate network in lead borate glasses, while with increasing the concentration of $\mathrm{PbO}$, the absorption bands below $620 \mathrm{~cm}^{-1}$ are attributed. Moreover, with in content from 30 to $50 \mathrm{~mol} \%$ of $\mathrm{PbO}$, bands related to the $\left[\mathrm{BO}_{4}\right]$ unit shifts from $945 \mathrm{~cm}^{-1}$ to a lower wavenumber $931 \mathrm{~cm}^{-1}$. Boroxol ring formation in the glassy matrix at wavenumber $806 \mathrm{~cm}^{-1}$ in lead borate glasses was observed while its formation inside the glassy matrix of Cd-doped $\mathrm{PbO}-\mathrm{B}_{2} \mathrm{O}_{3}$ glasses was not observed in IR spectra. This may be lead to the conclusion that the addition of $\mathrm{Cd}$ in glassy matrix deformed the boroxol ring. The conversion of three-fold to four-fold coordination of boron atoms in the structure of glasses was also observed in $\mathrm{Cd}$-doped $\mathrm{PbO}-\mathrm{B}_{2} \mathrm{O}_{3}$ glasses. Similarly, the presence of a stretching vibration of $\mathrm{B}-\mathrm{O}-\mathrm{M}(\mathrm{B}-\mathrm{O}-\mathrm{Pb})$ linkage, where " $M$ " represents a metal ion in the glassy matrix of $\mathrm{Cd}, \mathrm{Pb}$, $\mathrm{Ba}, \mathrm{Mo}$, and so forth, doped borate glasses also confirmed by IR spectra and assigned near $992 \mathrm{~cm}^{-1}$. The absorption 
band at $696 \mathrm{~cm}^{-1}$ is due to combined vibration of $\mathrm{BO}_{4}$ and $\mathrm{PbO}_{4}$ groups. The addition of lead in borate glass system modified the network of glassy matrix. Asymmetric stretching relaxation of $\mathrm{B}-\mathrm{O}$ bonds of trigonal $\mathrm{BO}_{3}$ units and composite of two silicate chain and borate phases have been presented in various vibration modes such as diborate, triborate, tetraborate, orthoborate, and pyroborate in the wavenumber regions of $1200-1750 \mathrm{~cm}^{-1}$ and 700 $1200 \mathrm{~cm}^{-1}$. These networks significantly affected by additives in borate glasses. In borosilicate glasses, the addition vibrations due to presence of silica were also observed, and these vibrations present basically two forms. Firstly, the stretching vibration of $\mathrm{B}-\mathrm{O}-\mathrm{Si}$ linkages, and secondly, they may be found as stretching vibrations of $\mathrm{Si}-\mathrm{O}-\mathrm{Si}$. The metallic cations vibrations in glassy matrix may be attributed in low wavenumber sides $\left(<600 \mathrm{~cm}^{-1}\right)$.

\section{Acknowledgments}

C. R. Gautam is grateful to the University Grant Commission (UGC), New Delhi, India, for providing the financial support as a Major Research Project (File no. 37-439/2009 (SR)). C. R. Gautam and A. K. Yadav are also thankful to Uttar Pradesh Council of Science and Technology (UPCST), Lucknow, India, for providing partial financial support under "Young Scientist Scheme Research Project" (no. CSTT/YSS/D-3913). The authors also acknowledge the facilities provided by the Head Department of Physics, University of Lucknow, Lucknow 226007, India.

\section{References}

[1] M. Yamane and Y. Asahara, Glasses for Photonics, Cambridge University Press, Cambridge, UK, 2000.

[2] S. Murugavel and B. Roling, "Ion transport mechanism in borate glasses: influence of network structure on nonArrhenius conductivity," Physical Review B, vol. 76, Article ID 180202, 4 pages, 2007.

[3] G. D. Khattak, N. Tabet, and L. E. Wenger, "Structural properties of glasses in the series $(\mathrm{SrO})_{x}\left(\mathrm{~V}_{2} \mathrm{O}_{5}\right)_{1-x},(\mathrm{SrO})_{0.5-y}$ $\left(\mathrm{B}_{2} \mathrm{O}_{3}\right)_{y}\left(\mathrm{~V}_{2} \mathrm{O}_{5}\right)_{0.5}$, and $(\mathrm{SrO})_{0.2}\left(\mathrm{~B}_{2} \mathrm{O}_{3}\right) \mathrm{z}\left(\mathrm{V}_{2} \mathrm{O}_{5}\right)_{0.8-z}, "$ Physical Review B, vol. 72, no. 10, Article ID 104203, 12 pages, 2005.

[4] G. S. Murugan, E. Fargin, V. Rodriguez et al., “Temperatureassisted electrical poling of $\mathrm{TeO}_{2}-\mathrm{Bi}_{2} \mathrm{O}_{3}-\mathrm{ZnO}$ glasses for nonlinear optical applications," Journal of Non-Crystalline Solids, vol. 344, no. 3, pp. 158-166, 2004.

[5] W. H. Dumbaugh and J. C. Lapp J, "Heavy-metal oxide glasses," Journal of the American Ceramic Society, vol. 75, no. 9, pp. 2315-2326, 1992.

[6] F. H. El-Batal, M. A. Azooz, and F. M. Ezz-Eldin, "Thermal expansion and infrared studies of binary $\mathrm{Bi}_{2} \mathrm{O}_{3}-\mathrm{B}_{2} \mathrm{O}_{3}$ and ternary $\mathrm{Bi}_{2} \mathrm{O}_{3}-\mathrm{B}_{2} \mathrm{O}_{3}-\mathrm{PbO}$ glasses," Physics and Chemistry of Glasses, vol. 43, no. 5, pp. 260-266, 2002.

[7] K. J. Rao, B. G. Rao, and S. R. Elliot, "Glass formation in the system $\mathrm{PbO}-\mathrm{PbCl}_{2}$," Journal of Materials Science, vol. 20, no. 5, pp. 1678-1682, 1985.

[8] V. C. V. Gowda, R. V. Anavekar, and K. J. Rao, "Elastic properties of fast ion conducting lithium based borate glasses," Journal of Non-Crystalline Solids, vol. 351, no. 43-45, pp. 3421-3429, 2005.
[9] S. Anderson, R. L. Bohon, and I. D. Kimpton J, "Infrared spectra and atomic arrangement in fused boron oxide and soda borate glasses," Journal of the American Ceramic Society, vol. 38, no. 10, pp. 370-377, 1955.

[10] J. Wang and C. A. Agell, Glass Structure By Spectroscopy, chapter 7, Dekker, New York, NY, USA, 1976.

[11] B. Schrader, Inferared and Raman Spectroscopy, John Wiley and Sons, London, UK, 1995.

[12] J. R. Ferraro and J. S. Jiomek, Introductory Group Theory and Its Applications to Molecular Structure, Plenum Press, New York, NY, USA, 1969.

[13] D. L. Rouseau, R. P. Bauman, and S. P. S. Porto, "Normal mode determination in crystals," Journal of Raman Spectroscopy, vol. 10, no. 1, pp. 253-290, 1981.

[14] W. G. Feteley, F. R. Dolish, N. T. McDewitt, and F. F. Bentley, Infered and Raman Selection Rules for Molecular and Lattice Vibrations, the Correlation Mathod, John Wiley and Sons, London, UK, 1995.

[15] A. M. Efimov, "Quantitative IR spectroscopy: applications to studying glass structure and properties," Journal of NonCrystalline Solids, vol. 203, pp. 1-11, 1996.

[16] D. L. Griscom, Borate Glasses: Structure, Properties and Applications, Plenum, New York, NY, USA, 1978.

[17] U. Selvaraj and K. J. Rao, "Infrared spectroscopic study of mixed-alkali effect in borate glasses," Spectrochimica Acta Part A, vol. 40, no. 11-12, pp. 1081-1085, 1984.

[18] E. I. Kamitsos, M. A. Karakassides, and G. D. Chryssikos, "A vibrational study of lithium sulfate based fast ionic conducting borate glasses," Journal of Physical Chemistry, vol. 90, no. 19, pp. 4528-4533, 1986.

[19] E. I. Kamitsos, M. A. Karakassides, and G. D. Chryssikos, "Cation-network interactions in binary alkali metal borate glasses. A far-infrared study," Journal of Physical Chemistry, vol. 91, no. 22, pp. 5807-5813, 1987.

[20] E. I. Kamitsos, G. D. Chryssikos, A. P. Patsis, and M. A. Karakassides, "Lithium conducting borate glasses: evidence for two broad distributions of cation-hosting environments," Journal of Non-Crystalline Solids, vol. 131-133, no. 2, pp. 1092-1095, 1991.

[21] U. Harder, P. Reich, and M. Willfahrt, "Infrared reflection measurements of lead Borate glasses," ournal of Molecular Structure, vol. 349, pp. 297-300, 1995.

[22] A. H. Verhoef and H. W. den Hartog, "Infrared spectroscopy of network and cation dynamics in binary and mixed alkali borate glasses," Journal of Non-Crystalline Solids, vol. 182, no. 3, pp. 221-234, 1995.

[23] A. H. Verhoef and H. W. den Hartog, "Infrared spectroscopy of network and cation dynamics in binary and mixed alkali borate glasses," Journal of Non-Crystalline Solids, vol. 182, no. 3, pp. 221-234, 1995.

[24] G. Dalba, P. Fornasini, F. Rocca, and F. Monti, "Short range order in borate glasses investigated by X-ray absorption spectroscopy," Physics and Chemistry of Glasses, vol. 41, pp. 290-295, 2000.

[25] L. Bih, M. El Omari, J. M. Réau et al., "Electronic and ionic conductivity of glasses inside the $\mathrm{Li}_{2} \mathrm{O}-\mathrm{MoO}_{3}-\mathrm{P}_{2} \mathrm{O}_{5}$ system," Solid State Ionics, vol. 132, no. 1, pp. 71-85, 2000.

[26] H. S. Liu, T. S. Chin, and S. W. Yung, "FTIR and XPS studies of low-melting $\mathrm{PbO}-\mathrm{ZnO}-\mathrm{P}_{2} \mathrm{O}_{5}$ glasses," Chemistry and Physics, vol. 50, no. 1, pp. 1-10, 1997.

[27] D. Stentz, S. Blair, C. Goater, S. Feller, and M. Affatigato, "Analysis of the structure of lead borosilicate glasses using laser ionization time of flight mass spectroscopy," Journal of Non-Crystalline Solids, vol. 293-295, no. 1, pp. 416-421, 2001. 
[28] M. Abid, M. Et-Tabirou, and M. Taibi, "Structure and DC conductivity of lead sodium ultraphosphate glasses," Materials Science and Engineering B, vol. 97, no. 1, pp. 20-24, 2003.

[29] P. J. Bray, M. Leventhal, and H. O. Hooper, "Nuclear magnetic resonance investigations of the structure of lead borate glasses," Physics and Chemistry of Glasses, vol. 4, no. 2, pp. 47-66, 1963.

[30] B. N. Meera, A. K. Sood, N. Chandrabhas, and J. Ramakrishna, "Raman study of lead borate glasses," Journal of NonCrystalline Solids, vol. 126, no. 3, pp. 224-230, 1990.

[31] Z. Pan, S. H. Morgan, and B. H. Long, "Raman scattering cross-section and non-linear optical response of lead borate glasses," Journal of Non-Crystalline Solids, vol. 185, no. 1-2, pp. 127-134, 1995.

[32] J. M. Wu and H. L. Huang, "Microwave properties of zinc, barium and lead borosilicate glasses," Journal of NonCrystalline Solids, vol. 260, no. 1-2, pp. 116-124, 1999.

[33] P. Srivastava, S. B. Rai, and D. K. Rai, "Effect of lead oxide on optical properties of $\mathrm{Pr}^{3+}$ doped some borate based glasses," Journal of Alloys and Compounds, vol. 368, no. 1-2, pp. 1-7, 2004.

[34] N. Singh, K. J. Singh, K. Singh, and H. Singh, "Comparative study of lead borate and bismuth lead borate glass systems as gamma-radiation shielding materials," Nuclear Instruments and Methods in Physics Research, Section B, vol. 225, no. 3, pp. 305-309, 2004.

[35] Y. Cheng, H. Xiao, W. Guo, and W. Guo, "Structure and crystallization kinetics of $\mathrm{PbO}-\mathrm{B}_{2} \mathrm{O}_{3}$ glasses," Ceramics International, vol. 33, no. 7, pp. 1341-1347, 2007.

[36] E. I. Kamitsos, A. P. Patsis, M. A. Karakassides, and G. D. Chryssikos, "Infrared reflectance spectra of lithium borate glasses," Journal of Non-Crystalline Solids, vol. 126, no. 1-2, pp. 52-67, 1990.

[37] A. K. Hassan, L. Börjesson, and L. M. Torell, "The boson peak in glass formers of increasing fragility," Journal of NonCrystalline Solids, vol. 172-174, no. 1, pp. 154-160, 1994.

[38] W. L. Konijnendijk and H. Verweij, "Structural aspects of vitreous $\mathrm{PbO} \cdot 2 \mathrm{~B}_{2} \mathrm{O}_{3}$ studied by Raman scattering," Journal of the American Ceramic Society, vol. 59, no. 9-10, pp. 459461, 1976.

[39] K. El-Egili, H. Doweidar, Y. M. Moustafa, and I. Abbas, "Structure and some physical properties of $\mathrm{PbO}-\mathrm{P}_{2} \mathrm{O}_{5}$ glasses," Physica B, vol. 339, no. 4, pp. 237-245, 2003.

[40] G. El-Damrawi and K. El-Egili, "Characterization of novel $\mathrm{CeO} 2-\mathrm{B}_{2} \mathrm{O}_{3}$ glasses, structure and properties," Physica $B$, vol. 299, no. 1-2, pp. 180-186, 2001.

[41] P. J. Bray, S. A. Feller, G. E. Jellison, and Y. H. Yun, "B10 NMR studies of the structure of borate glasses," Journal of Non-Crystalline Solids, vol. 38-39, no. 1, pp. 93-98, 1980.

[42] J. Lorösch, M. Couzi, J. Pelous, R. Vacher, and A. Levasseur, "Brillouin and raman scattering study of borate glasses," Journal of Non-Crystalline Solids, vol. 69, no. 1, pp. 1-25, 1984.

[43] E. N. Boulos and N. J. Kreidl J, "Structure and properties of silver borate glasses," Journal of the American Ceramic Society, vol. 54, no. 8, pp. 368-375, 1971.

[44] M. P. Teter, "Glass structure using quantum molecular dynamics," in Proceedings of the 89th Annual Meeting American Ceramic Society, p. 231, Pittsburgh, Russia, 1987.

[45] L. Shartsis and S. Spinner, "Viscosity and density of molten optical glasses," Journal of Research of the National Bureau of Standards, vol. 46, no. 3, pp. 176-194, 1951.
[46] P. J. Bray and J. G. O’Keefe, "Nuclear magnetic resonance investigations of the structure of alkali borate glasses," Physics and Chemistry of Glasses, vol. 4, pp. 37-46, 1963.

[47] R. Brueckner, H. U. Chun, H. Goretzki, and M. Sammet, "XPS measurements and structural aspects of silicate and phosphate glasses," Journal of Non-Crystalline Solids, vol. 42, no. $1-3$, pp. 49-60, 1980.

[48] J. Schwarz and H. Ticha, "Some optical properties of $\mathrm{BaO}-\mathrm{PbO}-\mathrm{B}_{2} \mathrm{O}_{3}$ glasses," The Journal of Optoelectronics and Advanced Materials, vol. 5, no. 1, pp. 69-74, 2003.

[49] A. A. Alemi, H. Sedghi, A. R. Mirmohseni, and V. Golsanamlu, "Synthesis and characterization of cadmium doped lead-borate glasses," Bulletin of Materials Science, vol. 29, no. 1, pp. 55-58, 2006.

[50] P. S. Prasad, M. S. Reddy, V. R. Kumar, and N. Veeraiah, "Spectroscopic and dielectric studies on $\mathrm{PbO}-\mathrm{MoO}_{3}-\mathrm{B}_{2} \mathrm{O}_{3}$ glasses incorporating small concentrations of $\mathrm{TiO}_{2}$," Philosophical Magazine, vol. 87, no. 36, pp. 5763-5787, 2007.

[51] S. G. Motke, S. P. Yawale, and S. S. Yawale, "Infrared spectra of zinc doped lead borate glasses," Bulletin of Materials Science, vol. 25, no. 1, pp. 75-78, 2002.

[52] N. M. Bobkova, "Study of the properties of bismuth-borate systems toward low-melting lead-free glasses," Glass Physics and Chemistry, vol. 38, no. 1, pp. 180-183, 2012.

[53] J. Singh, S. P. Singh, D. Singh, G. S. Mudahar, and K. S. Thind, "Optical characterization of fly ash as a glass modifier in potassium borate glasses," Materials Physics and Mechanics, vol. 11, no. 1, pp. 17-22, 2011.

[54] G. Padmaja and P. Kistaiah, "Infrared and raman spectroscopic studies on alkali borate glasses: evidence of mixed alkali effect," Journal of Physical Chemistry A, vol. 113, no. 11, pp. 2397-2404, 2009.

[55] H. Aboud, H. Wagiran, I. Hossain, and R. Hussin, "Infrared spectra and energy band gap of potassium lithium borate glass dosimetry," International Journal of Physical Sciences, vol. 7, pp. 922-926, 2012.

[56] N. J. Kreidl, Inorganic Glass-Forming Systems in Glass: Science and Technology, vol. 1 of Glass-Forming Systems, Academic Press, New York, NY, USA, 1983.

[57] A. Aronne, S. Esposito, and P. Pernice, "FTIR and DTA study of structural transformations and crystallisation in $\mathrm{BaO}-\mathrm{B}_{2} \mathrm{O}_{3}-\mathrm{TiO}_{2}$ glasses," Journal of Physics and Chemistry of Glasses, vol. 40, no. 2, pp. 63-68, 1999.

[58] G. E. Jellison and P. J. Bray, "A structural interpretation of B10 and B11 NMR spectra in sodium borate glasses," Journal of Non-Crystalline Solids, vol. 29, no. 2, pp. 187-206, 1978.

[59] F. L. Galeener, G. Lucovsky, and J. C. Mikkelsen Jr., "Vibrational spectra and the structure of pure vitreous $\mathrm{B}_{2} \mathrm{O}_{3}$," Physical Review B, vol. 22, no. 8, pp. 3983-3990, 1980.

[60] K. Shimakawa, "On the compositional dependence of the optical gap in amorphous semiconducting alloys," Journal of Non-Crystalline Solids, vol. 43, no. 2, pp. 229-244, 1981.

[61] M. Pal, B. Roy, and M. Pal, "Structural characterization of borate glasses containing zinc and manganese oxides," Journal of Modern Physics, vol. 2, pp. 1062-1066, 2011.

[62] A. K. Srivastava, "Fuzzy topology at the Banaras Hindu University, Varanasi (India)," Fuzzy Sets and Systems, vol. 25, no. 3, pp. 381-382, 1988.

[63] C. R. Gautam, D. Kumar, and O. Parkash, "IR study of Pb-Sr titanate borosilicate glasses," Bulletin of Materials Science, vol. 33, no. 2, pp. 145-148, 2010.

[64] A. K. Yadav and C. R. Gautam, "IR and Raman Spectroscopy of $(\mathrm{Ba}, \mathrm{Sr}) \mathrm{TiO}_{3}$ Borosilicate Glass Doped with $\mathrm{La}_{2} \mathrm{O}_{3}$," Lucknow Journal of Science, vol. 8, pp. 26-30, 2011. 
[65] V. E. Eremyashev, A. A. Osipov, and L. M. Osipova, "Borosilicate glass structure with rare-earth-metal cations substituted for sodium cations," Glass and Ceramics, vol. 68, no. 7-8, pp. 205-208, 2011.

[66] Q. Chen, Q. Chen, and S. Wang, "A new Faraday rotation measurement method for the study on magneto optical property of $\mathrm{PbO}-\mathrm{Bi}_{2} \mathrm{O}_{3}-\mathrm{B}_{2} \mathrm{O}_{3}$ glasses for current sensor applications," Open Journal of Inorganic Non-metallic Materials, vol. 1, pp. 1-7, 2011.

[67] K. El-Egili and A. H. Oraby, "The structure and electrical properties of lithium borate glasses containing thallic oxide," Journal of Physics Condensed Matter, vol. 8, no. 46, pp. 89598970, 1996.

[68] A. R. Kulkarni, H. S. Maiti, and A. Paul, "Fast ion conducting lithium glasses-review," Bulletin of Materials Science, vol. 6, no. 2, pp. 201-221, 1984.

[69] M. A. Kanehisa and R. J. Elliot, "Vibrations of boron oxide glass," Materials Science and Engineering B, vol. 3, no. 1-2, pp. 163-166, 1989.

[70] R. V. Adams and R. W. Douglas, "Infra-red studies on various samples of fused silica with special reference to the bands due to water," Journal of The Society of Glass Technology, vol. 43, pp. 147-158, 1959.

[71] H. Scholzelt, Glass: Nature, Structure and Properties, Springer, New York, NY, USA, 1991.

[72] J. Krogh-Moe, "Interpretation of the infra-red spectra of boron oxide and alkali borate glasses," Physics and Chemistry of Glasses, vol. 6, pp. 46-54, 1965.

[73] N. A. Ghoneim, H. A. El Batal, N. Abdel Shafi, and M. H. Azooz, "Synthesis and Characterization of Cadmium Doped Lead-Borate Glasses," in Proceeding of the Egyptian Conference of Chemistry, p. 162, Cairo, Egypt, 1996.

[74] V. G. Chekhovskii, "The Interpretation of IR Spectra of Alkali Borate Glasses," Fizika i Khimiya Stekla, vol. 11, p. 24.

[75] H. M. Heaton and H. Moore, Journal Physics and Chemistry of Glasses, vol. 28, p. 203, 1987.

[76] J. Biscoe and B. E. Warren, "X-ray diffraction study of sodaboric oxide glass," Journal of the American Ceramic Society, vol. 21, no. 8, pp. 287-293, 1938.

[77] M. F. Mydlar, N. J. Kreidl, and J. K. Hendren, "X-ray diffraction study of lead silicate glasses," Physics and Chemistry of Glasses, vol. 11, p. 198, 1970.

[78] U. Selveraj and K. J. Rao, "Role of lead in lead phosphomolybdate glasses and a model of structural units," Journal of Non-Crystalline Solids, vol. 104, no. 2-3, pp. 300-315, 1988.

[79] A. Varshneya, Fundamentals of Inorganic Glasses, Academic Press, New York, NY, USA, 1994.

[80] A. Venktaraman, V. A. Hiremath, S. K. Date, and S. D. Kulkarni, "A new combustion route to $\gamma-\mathrm{Fe}_{2} \mathrm{O}_{3}$ synthesis," Bulletin of Materials Science, vol. 24, no. 6, pp. 617-621, 2001.

[81] G. Sharma, K. Singh, Manupriya, S. Mohan, H. Singh, and S. Bindra, "Effects of gamma irradiation on optical and structural properties of $\mathrm{PbO}-\mathrm{Bi}_{2} \mathrm{O}_{3}-\mathrm{B}_{2} \mathrm{O}_{3}$ glasses," Radiation Physics and Chemistry, vol. 75, no. 9, pp. 959-966, 2006.

[82] T. F. Soules, "A molecular dynamic calculation of the structure of $\mathrm{B}_{2} \mathrm{O}_{3}$ glass," The Journal of Chemical Physics, vol. 73, no. 8, pp. 4032-4036, 1980.

[83] K. Nakamoto, Infrared \& Raman Spectra of Inorganic \& Coordination Compounds, John Wiley, New York, NY, USA, 4th edition, 1992.

[84] A. S. Tenny and J. Wong, "Vibrational spectra of vapordeposited binary borosilicate glasses," Journal of Chemical Physics, vol. 56, pp. 5516-5523, 1972.
[85] H. M. Heaton and H. Moore, "The sources of the infra-red absorption bands observed in the trans-mission curves of the glasses," Journal of the Society of Glass Technology, vol. 41, p. 28, 1957.

[86] C. Gejke, E. Zanghellini, J. Swenson, and L. Börjesson, "Microscopic structure of tin-borate and tin-boratephosphate glasses," Journal of Power Sources, vol. 119-121, pp. 576-580, 2003.

[87] I. Waclawska, "Glass transition effect of amorphous borates ," Thermochimica Acta, vol. 269, pp. 457-464, 1995.

[88] R. C. lucacel and I. Ardelean, "Comparative structural investigation of $\mathrm{B}_{2} \mathrm{O}_{3}-\mathrm{MO}-\mathrm{CuO}$ glasses $\left(\mathrm{MO} \rightarrow \mathrm{TeO}_{2}\right.$ or $\mathrm{As}_{2} \mathrm{O}_{3}$ ) by FTIR and Raman spectroscopies," Journal of Optoelectronics and Advanced Materials, vol. 8, pp. 1124-1128, 2006.

[89] A. M. Azhra and C. Y. Zahra, "DSC and Raman studies of lead borate and lead silicate glasses," Journal of Non-Crystalline Solids, vol. 155, pp. 45-55, 1993.

[90] P. G. Bray and J. G. O'Keefe, "Nuclear magnetic resonance investigations of the structure of alkali borate glasses," Physics and Chemistry of Glasses, vol. 4, pp. 37-46, 1963.

[91] H. Doweidar, M. A. A. Zeid, and G. M. El-Damrawy, "Effect of gamma radiation and thermal treatment on some physical properties of $\mathrm{ZnO}-\mathrm{PbO}-\mathrm{B}_{2} \mathrm{O}_{3}$ glasses," Journal of Physics D, vol. 24, no. 12, pp. 2222-2228, 1991.

[92] S. P. Yawale, S. V. Pakade, and C. S. Adgaonkar, "Infrared spectra of some borate glasses," Indian Journal of Pure and Applied Physics, vol. 33, pp. 34-37, 1995.

[93] S. A. Feller, N. Lower, and M. Affatigato, "Density as a probe of oxide glass structure," Physics and Chemistry of Glasses, vol. 42, no. 3, pp. 240-246, 2001.

[94] E. I. Kamitsos, "Infrared studies of borate glasses," Physics and Chemistry of Glasses, vol. 44, no. 2, pp. 79-87, 2003.

[95] A. Karki, S. Feller, H. P. Lim, J. Stark, C. Sanchez, and M. Shibata, "The density of sodium-borate glasses related to atomic arrangements," Journal of Non-Crystalline Solids, vol. 92, no. 1, pp. 11-19, 1987.

[96] H. P. Lim and S. Feller, "The density of low metal content rubidium, cesium, silver, and thallium borate glasses related to atomic arrangements," Journal of Non-Crystalline Solids, vol. 94, no. 1, pp. 36-44, 1987.

[97] W. Soppe, J. Kleerebezem, and H. W. D. Hartog, "Raman spectroscopy study of $\left(\mathrm{B}_{2} \mathrm{O}_{3}\right)_{1-x-y}\left(\mathrm{Li}_{2} \mathrm{O}\right)_{x} \quad\left(\mathrm{Li}_{2} \mathrm{Cl}_{2}\right)_{y}$ and $\left(\mathrm{B}_{2} \mathrm{O}_{3}\right)_{1-x-y}\left(\mathrm{Li}_{2} \mathrm{O}\right)_{x}\left(\mathrm{Cs}_{2} \mathrm{O}\right)_{y}$, Journal of Non-Crystalline Solids, vol. 93, no. 1, pp. 142-154, 1987.

[98] Y. Ito and K. Miyauchi, "Ionic conductivity of $\mathrm{Li}_{2} \mathrm{OB}_{2} \mathrm{O}_{3}$ thin films," Journal of Non-Crystalline Solids, vol. 57, no. 3, pp. 389-400, 1983.

[99] A. Abou Shama and F. H. El-Batal, "Structural analysis of glassy lead borate containing $\mathrm{MoO}_{3}$ in relation to its optical properties," Egyptian Journal of Solids, vol. 29, no. 1, pp. 4967, 2006.

[100] G. El-Deen and A. E.-R. Yahya, "Studies on some lithiumborate glasses containing iron and copper," Turkish Journal Of Physics, vol. 27, pp. 255-262, 2003.

[101] A. Moguš-Milanković, A. Šantić, A. Gajović, and D. E. Day, "Spectroscopic investigation of $\mathrm{MoO}_{3}-\mathrm{Fe}_{2} \mathrm{O}_{3}-\mathrm{P}_{2} \mathrm{O}_{5}$ and SrO$\mathrm{Fe}_{2} \mathrm{O}_{3}-\mathrm{P}_{2} \mathrm{O}_{5}$ glasses. Part I," Journal of Non-Crystalline Solids, vol. 325, no. 1-3, pp. 76-84, 2003.

[102] T. Hubert, U. Harder, G. Mosel, and K. Witke, "Structural investigations of lead and strontium borate glasses," in Proceedings of the 2nd International Conference on Borates Glasses, Crystals and Melts, A. C. Wright, S. A. Feller, and A. C. Hannon, Eds., pp. 156-163, Society of Glass Technology, Sheffield, UK, 1997. 
[103] P. Znášik and M. Jamnický, "Preparation, infrared spectra and structure of glasses in the system $\mathrm{CuCl}-\mathrm{Cu}_{2} \mathrm{O}-\left(\mathrm{P}_{2} \mathrm{O}_{5}+\right.$ $\mathrm{MoO}_{3}$ )," Journal of Non-Crystalline Solids, vol. 146, no. C, pp. 74-80, 1992.

[104] C. P. Varsamis, E. I. Kamitsos, N. Machida, and T. Minami, "Coordination states of molybdenum and the nature of copper ion sites in the superionic glasses xCuI $\cdot(1-\mathrm{X}) \mathrm{Cu}_{2} \mathrm{MoO}_{2}$ $(\mathrm{x}=0.4,0.5)$ studied by infrared reflectance spectroscopy," Journal of Physical Chemistry B, vol. 101, no. 19, pp. 37343741, 1997.

[105] A. A. El-Kheshen, F. H. El-Batal, and S. Y. Marzouk, "UVvisible, infrared and Raman spectroscopic and thermal studies of tungsten doped lead borate glasses and the effect of ionizing gamma irradiation," Indian Journal of Pure and Applied Physics, vol. 46, no. 4, pp. 225-238, 2008.

[106] M. Leventhal and P. J. Bray, "Nuclear magnetic resonance investigations of compounds and glasses in the systems $\mathrm{PbO}$ $\mathrm{B}_{2} \mathrm{O}_{3}$ and $\mathrm{PbO}-\mathrm{SiO}_{2}$," Physics and Chemistry of Glasses, vol. 6, pp. 113-125, 1966.

[107] A. A. Ahmed, N. Abd Elshafi, and M. R. Eltohamy, Indian Journal of Pure and Applied Physics, vol. 36, p. 335, 1998.

[108] G. Govindaraj, N. Baskaran, K. Shahi, and P. Monoravi, "Preparation, conductivity, complex permittivity and electric modulus in $\mathrm{AgIAg}_{2} \mathrm{OSeO}_{3} \mathrm{MoO}_{3}$ glasses," Solid State Ionics, vol. 76, no. 1-2, pp. 47-55, 1995.

[109] N. Machida and H. Eckert, "FT-IR, FT-Raman and 95Mo MAS-NMR studies on the structure of ionically conducting glasses in the system $\mathrm{AgI}-\mathrm{Ag}_{2} \mathrm{O}-\mathrm{MoO}_{3}$," Solid State Ionics, vol. 107, no. 3-4, pp. 255-268, 1998.

[110] P. G. Bray, Interaction of Radiation with Solids, Plenum, New York, NY, USA, 1967.

[111] H. Dunken and R. H. Doremus, "Short time reactions of a $\mathrm{Na}_{2} \mathrm{O}-\mathrm{CaO}-\mathrm{SiO}_{2}$ glass with water and salt solutions," Journal of Non-Crystalline Solids, vol. 92, no. 1, pp. 61-72, 1987.

[112] R. D. Husung and R. H. Doremus, "Infrared transmission spectra of four silicate glasses before and after exposure to water," Journal of Materials Research, vol. 5, no. 10, pp. 22092217, 1990.

[113] E. I. Kamitsos, M. A. Karakassides, and G. D. Chryssikos, "Vibrational spectra of magnesium-sodium-borate glasses. 2. Raman and mid-infrared investigation of the network structure," Journal of Physical Chemistry, vol. 91, no. 5, pp. 1073-1079, 1987.

[114] F. M. Ezz-Eldin, N. A. E. L. Alaily, F. A. Khalifa, and H. A. E. L. Batal, "Fundamental of glass science and technology," in Proceedings of the 3rd ESG Conference, Verlag Der Deutschen Glastechnischen Gesellschaft, Germany, 1995.

[115] E. A. Davis and N. F. Mott, "Conduction in non-crystalline systems V," Philosophical Magazine, vol. 22, no. 179, pp. 903922, 1970

[116] H. B. George, C. Vira, C. Stehle et al., "A structural analysis of the physical properties of bismuth and lead based glasses," Physics and Chemistry of Glasses, vol. 40, no. 6, pp. 326-332, 1999.

[117] V. R. Kumar, N. Veeraiah, S. Buddhudu, and V. J. T. Raju, "Dielectric dispersion in $\mathrm{CuO}$ doped $\mathrm{ZnF}_{2}-\mathrm{PbO}-\mathrm{TeO}_{2}$ glasses," Journal de Physique III, vol. 7, no. 5, pp. 951-961, 1997.

[118] I. N. Chakraborty and D. E. Day, "Effect of $\mathrm{R}^{3+}$ ions on the structure and properties of lanthanum borate glasses," Journal of the American Ceramic Society, vol. 68, no. 12, pp. 641-645, 1985.
[119] J. C. Lapp and J. E. Shelby, "Structure-property relations in lanthanide borate glasses," Journal of the American Ceramic Society, vol. 68, no. 7, pp. 368-371, 1985.

[120] V. Dimitrov, Y. Dimitriev, and A. Montenero, "IR spectra and structure of $\mathrm{V}_{2} \mathrm{O}_{5} \mathrm{GeO}_{2} \mathrm{Bi}_{2} \mathrm{O}_{3}$ glasses," Journal of NonCrystalline Solids, vol. 180, no. 1, pp. 51-57, 1994.

[121] R. Lal and N. D. Sharma, "Infrared spectroscopic study of zinc doped iron borate glasses," Indian Journal of Pure and Applied Physics, vol. 43, no. 11, pp. 828-832, 2005.

[122] R. Lal, N. D. Sharma, H. K. Sharma, and K. Chandra, "Mössbauer and infrared studies of manganese doped iron borate glasses," Indian Journal of Pure and Applied Physics, vol. 42, no. 1, pp. 25-30, 2004.

[123] R. Lal, N. D. Sharma, and K. Chandra, "Mössbauer and infrared studies of some glasses and glass-ceramics from the $X \mathrm{MnO}(40-X) \mathrm{YFe}_{2} \mathrm{O}_{3} .10 \mathrm{Al}_{2} \mathrm{O}_{3} .50 \mathrm{~B}_{2} \mathrm{O}_{3}$ system," Indian Journal of Pure and Applied Physics, vol. 42, no. 7, pp. 498505, 2004.

[124] M. B. Saisudha and J. Ramakrishna, "Optical absorption of $\mathrm{Nd}^{3+}, \mathrm{Sm}^{3+}$ and $\mathrm{Dy}^{3+}$ in bismuth borate glasses with large radiative transition probabilities," Optical Materials, vol. 18, no. 4, pp. 403-417, 2002.

[125] H. B. Pan, X. L. Zhao, X. Zhang et al., "Strontium borate glass: potential biomaterial for bone regeneration," Journal of the Royal Society Interface, vol. 7, no. 48, pp. 1025-1031, 2010.

[126] H. A. El-Batal, F. A. Khalifa, and M. A. Azooz, "Gamma ray interaction, crystallization and infrared absorption spectra of some glasses and glass-ceramics from the system $\mathrm{Li}_{2} \mathrm{O}_{2} \mathrm{~B}_{2} \mathrm{O}_{3} \cdot \mathrm{Al}_{2} \mathrm{O}_{3}$," Indian Journal of Pure and Applied Physics, vol. 39, no. 9, pp. 565-573, 2001.

[127] W. Soppe, C. van der Marel, W. F. van Gunsteren, and H. W. den Hartog, "New insights into the structure of $\mathrm{B}_{2} \mathrm{O}_{3}$ glass," Journal of Non-Crystalline Solids, vol. 103, no. 2-3, pp. 201209, 1988.

[128] A. V. Egorysheva, V. I. Burkov, Y. F. Kargin, V. G. Plotnichenko, and V. V. Koltashev, "Vibrational spectra of crystals of bismuth borates," Crystallography Reports, vol. 50, no. 1, pp. 127-136, 2005.

[129] N. Atsusni, “Optisches Glas," Patent no. 102007050172, Germany, 2008.

[130] W. Qiao and P. Chena, "Study on the properties of $\mathrm{Bi}_{2} \mathrm{O}_{3}$ $\mathrm{B}_{2} \mathrm{O}_{3}-\mathrm{BaO}$ lead-free glass using in the electronic pastes," Glass Physics and Chemistry, vol. 36, no. 3, pp. 304-308, 2010.

[131] C. Yin, X. Hanning, and G. Wenning, "Influences of $\mathrm{La}^{3+}$ and $\mathrm{Er}^{3+}$ on structure and properties of $\mathrm{Bi}_{2} \mathrm{O}_{3}-\mathrm{B}_{2} \mathrm{O}_{3}$ glass," Ceramics International, vol. 34, no. 5, pp. 1335-1339, 2008.

[132] L. Stoch and M. Sroda, "Infrared spectroscopy in the investigation of oxide glasses structure " Journal of Molecular Structure, vol. 511-512, pp. 77-84, 1999.

[133] A. Pan and A. Ghosh, "New family of lead-bismuthate glass with a large transmitting window," Journal of Non-Crystalline Solids, vol. 271, no. 1, pp. 157-161, 2000.

[134] H. P. Lim, A. Karki, S. Feller, J. E. Kasper, and G. Sumcad, "The density of potassium borate glasses related to atomic arrangements," Journal of Non-Crystalline Solids, vol. 91, no. 3, pp. 324-332, 1987.

[135] R. D. Shannon, "Revised effective ionic radii and systematic studies of interatomic distances in halides and chalcogenides ," Acta Crystallographica A, vol. 32, pp. 751-767, 1976.

[136] J. Krogh-Moe, "The crystal structure of silver tetraborate $\mathrm{Ag}_{2} \mathrm{O}_{4} 4 \mathrm{~B}_{2} \mathrm{O}_{3}$," Acta Crystallographica, vol. 189, pp. 77-81, 1965. 
[137] I. Ardelean and M. Toderaş, "FTIR structural investigation of $3 \mathrm{~B}_{2} \mathrm{O}_{3}-\mathrm{BaO}$ glass matrix containing manganese ions," Journal of Optoelectronics and Advanced Materials, vol. 8, no. 3, pp. 1118-1120, 2006.

[138] S. Bale and S. Rahman, "Spectroscopic and physical properties of $\mathrm{Bi}_{2} \mathrm{O}_{3}-\mathrm{B}_{2} \mathrm{O}_{3}-\mathrm{ZnO}-\mathrm{Li}_{2} \mathrm{O}$ glasses," ISRN Spectroscopy, vol. 2012, Article ID 634571, 7 pages, 2012.

[139] R. A. Condrate, "Vibrational spectra of structural units in glass," Journal of Non-Crystalline Solids, vol. 84, no. 1-3, pp. 26-33, 1986.

[140] Y. Tetsuji, K. Noboru, S. Shuichi, and Y. Masayuki, "Structural investigation of sodium borate glasses and melts by Raman spectroscopy. II. Conversion between $\mathrm{BO}_{4}$ and $\mathrm{BO}_{2} \mathrm{O}$ - units at high temperature," Journal of Non-Crystalline Solids, vol. 321, no. 3, pp. 147-156, 2003.

[141] J. A. Duffy and M. D. Ingram, "Optical basicity-IV: influence of electronegativity on the Lewis basicity and solvent properties of molten oxyanion salts and glasses," Journal of Inorganic and Nuclear Chemistry, vol. 37, pp. 1203-1206, 1975.

[142] A. Ryichi, O. Norikazu, and U. Norimasa, "Raman spectra of $\mathrm{K}_{2} \mathrm{O}-\mathrm{B}_{2} \mathrm{O}_{3}$ glasses and melts," Journal of Non-Crystalline Solids, vol. 293, pp. 471-476, 2001.

[143] A. H. Verhoef and H. W. den Hartog, "A molecular dynamics study of $\mathrm{B}_{2} \mathrm{O}_{3}$ glass using different interaction potentials," Journal of Non-Crystalline Solids, vol. 146, no. C, pp. 267-278, 1992.

[144] S. Ram, "Infrared study of the dynamics of boroxol rings in the crystallization of $\mathrm{BaFe}_{12} \mathrm{O}_{19}$ microcrystals in borate glasses," Physical Review B, vol. 51, no. 10, pp. 6280-6286, 1995.

[145] N. M. Bobkova and S. A. Khot'ko, "Zinc oxide in borate glassforming systems," Glass and Ceramics, vol. 62, no. 5-6, pp. 167-170, 2005.

[146] E. I. Kamitsos and M. A. Karakassides, "Structural studies of binary and pseudo binary sodium borate glasses of high sodium content," Physics and Chemistry of Glasses, vol. 30, no. 1, pp. 19-26, 1989.

[147] K. El-Egili, "Infrared studies of $\mathrm{Na}_{2} \mathrm{O}-\mathrm{B}_{2} \mathrm{O}_{3}-\mathrm{SiO}_{2}$ and $\mathrm{Al}_{2} \mathrm{O}_{3}$ $\mathrm{Na}_{2} \mathrm{O}-\mathrm{B}_{2} \mathrm{O}_{3}-\mathrm{SiO}_{2}$ glasses," Physica B, vol. 325, pp. 340-348, 2003.

[148] J. Wan, J. Cheng, and P. Lu, "The coordination state of B and $\mathrm{Al}$ of borosilicate glass by IR spectra," Journal of Wuhan University of Technology, vol. 23, no. 3, pp. 419-421, 2008.

[149] A. S. Tenny and J. J. Wong, "Vibrational spectra of vapordeposited binary borosilicate glasses," Chemical Physics, vol. 56, pp. 5516-5523, 1972.

[150] R. N. Sinclair, C. E. Stone, A. C. Wright et al., "Inelastic neutron scattering studies of superstructural units in borate glasses and crystalline phases," Physics and Chemistry of Glasses, vol. 41, no. 5, pp. 286-289, 2000. 

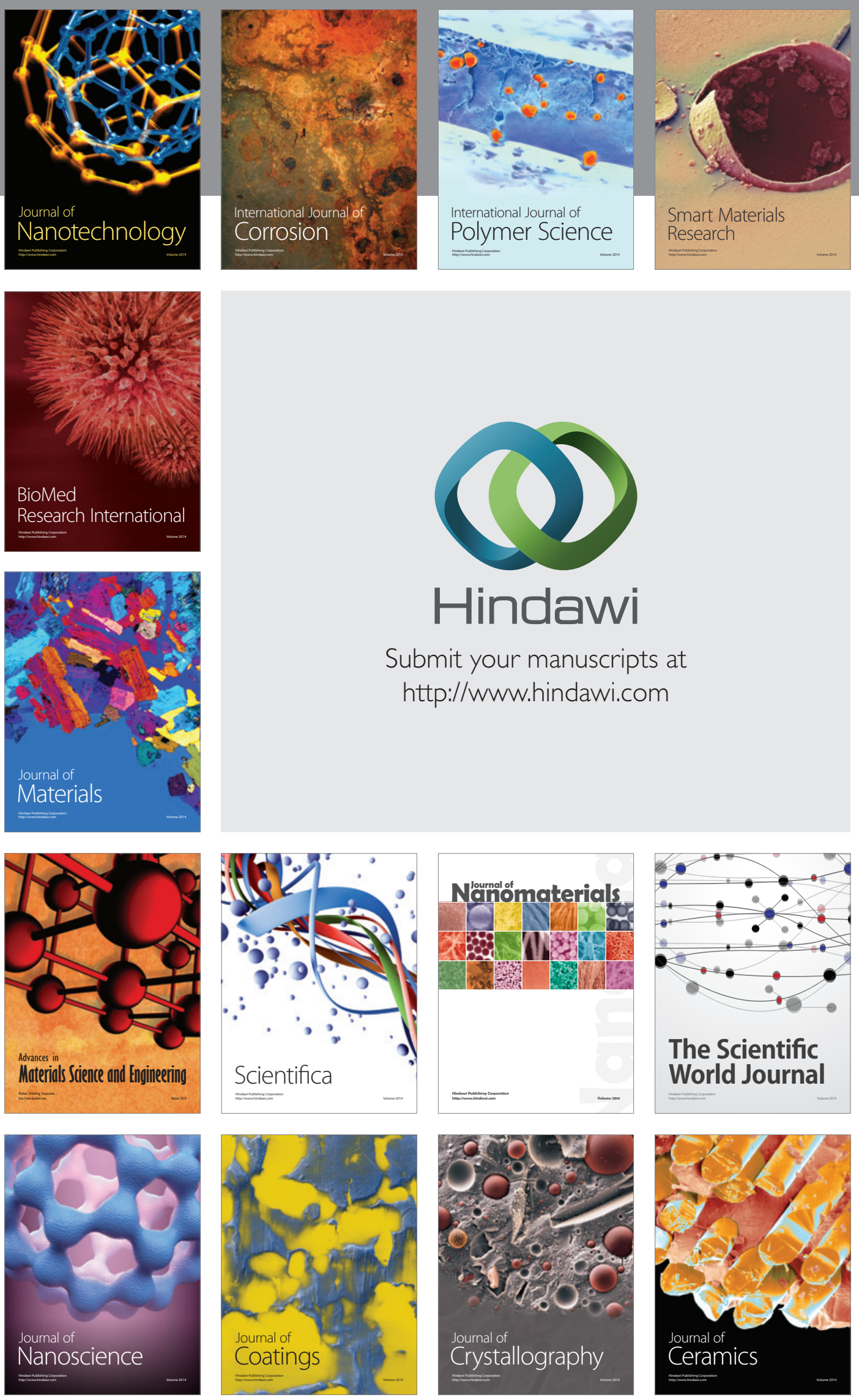

The Scientific World Journal

Submit your manuscripts at

http://www.hindawi.com

\section{World Journal}

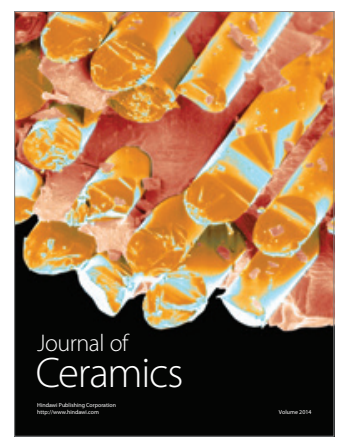

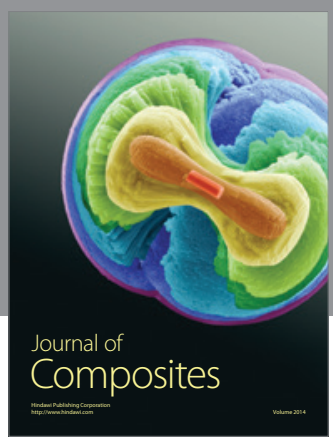
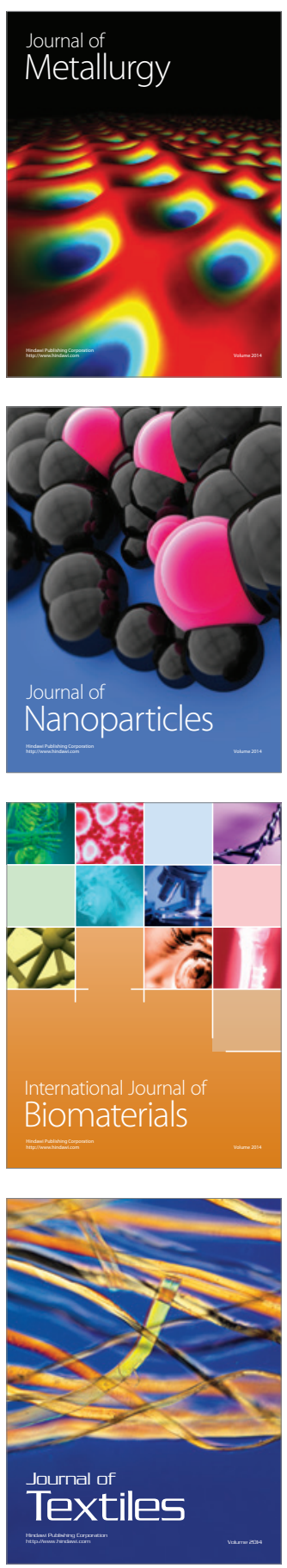